УДК 553.411.071/078

\title{
ЗОЛОТАЯ МИНЕРАЛИЗАЦИЯ ШТОКОВОГО РУДНОГО ПОЛЯ (Магаданская область)
}

\author{
Глухов А. Н., Фомина М. И., Колова Е. Е. \\ ФГБУН Северо-Восточный комплексный научно-исследовательский институт \\ им. Н. А. Шило ДВО РАН, г. Магадан \\ E-mail: gluhov76@list.ru
}

\begin{abstract}
Дана краткая геолого-структурная характеристика Штокового рудного поля, приуроченного к области наложения Хурчан-Оротуканской зоны тектоно-магматической активизации на структуры Яно-Колымского золотоносного пояса. Изучены минеральные ассоциации и физико-химические условия образования золотосодержащих рудных тел, локализованных как в гранитах, так и в ороговикованных осадочных толщах. По основным чертам геологического строения, составу руд и физико-химическим условиям образования минерализация Штокового рудного поля соответствует «глубинной» группе золото-редкометалльной формации, аналогично рудопроявлениям Бутарное, Басугуньинское, Дубач, Надежда. Спецификой его руд является наложение на синаккреционное золото-редкометалльное оруденение поздней эпитермальной минерализации, которая связана с Охотско-Чукотским вулканогенным поясом.
\end{abstract}

Ключевые слова: золото-редкометалльная формация, граниты, золото-серебряная минерализация, минералогия, термобарогеохимия, Хурчан-Оротуканская зона тектономагматической активизации.

DOI: $10.34078 / 1814-0998-2021-1-13-29$

Месторождения золото-редкометалльной формации (по международной терминологии «связанные с гранитоидами», далее - ЗРМ) широко распространены как на Северо-Востоке России, так и в пределах Северной Пацифики в целом. Им посвящен достаточно большой массив литературы (Шило и др., 1988; Горячев, 1998, 2003; Гамянин, 2001; Гамянин и др., 2003; Волков и др., 2011, 2013; Vikent'eva et al., 2018). Coгласно современным представлениям (Hart, 2007; Mair et al., 2011), ЗРМ формируются на завершающей стадии аккреционно-коллизионных процессов, тесно ассоциируют с месторождениями $\mathrm{Sn}, \mathrm{W}$ и являются продуктами эволюции магматических систем, представленных гранитоидами ильменитовой серии. В последние годы они, после длительного, растянувшегося на многие десятилетия геологического изучения, приобретают в регионе промышленное значение. Примерами являются вовлеченные в освоение месторождения Бутарное, Надежда и Тэутеджак. При всей схожести основных черт геологического строения и состава руд ЗРМ тем не менее характеризуются некоторыми индивидуальными чертами, которые отражают как региональ-

(C) Глухов А. Н., Фомина М. И., Колова Е. Е., 2021 ную металлогеническую специфику, так и особенности условий рудообразования. Нами изучено Штоковое рудное поле, которое приурочено к области наложения Хурчан-Оротуканской зоны тектоно-магматической активизации (ТМА) на структуры Яно-Колымского золотоносного пояса. Специфика Хурчан-Оротуканской зоны TMA, как и других аналогичных структур, широко развитых в задуговой части Охотско-Чукотского вулканогенного пояса (Кузнецов, 2006), заключается в тесной ассоциированности продуктов аккреционно-коллизионных и субдукционных процессов. Это выражается в пространственном совмещении и наложении вулканических образований и эпитермального $\mathrm{Au}-\mathrm{Ag}$ оруденения на интрузии коллизионных гранитоидов, несущих средне- и выскокотемпературную редкометалльную минерализацию. Такая геологическая позиция рассматриваемых объектов благоприятна для реконструкции последовательности упомянутых процессов. Ранее уже было установлено развитие в пределах Хурчан-Оротуканской зоны TMA золото-кварцевой (орогенной), золоторедкометалльной и золото-серебряной минерализации (Кузнецов и др., 2011). Следует отметить существование и альтернативной точки зрения, согласно которой серебряная минерализация 
данной структуры трактуется как один из минеральных типов золото-редкометалльной формации (Литвиненко, 2020). В основу данной статьи положен фактический материал, собранный при проведении поисковых работ в 2013-2014 гг.

\section{МЕТОДИКА ИССЛЕДОВАНИЙ}

Минеральный состав, текстурные, структурные особенности и минеральные парагенезисы изучались под оптическим микроскопом АХIOPLAN ZEISS в отраженном и проходящем свете. Составы минеральных фаз определяли с помощью рентгеновского электронно-зондового микроанализатора Camebax с приставкой INCA (г. Магадан, СВКНИИ ДВО РАН, аналитик Т. В. Субботникова)

Микротермометрические исследования флюидных включений (ФВ) осуществлены с использованием измерительного комплекса на основе микротермокамеры THMSG-600 фирмы Linkam, микроскопа Motic, снабженного длиннофокусным объективом 50X фирмы Olimpus и видеокамеры Moticam solution 3 M.pх в соответствии с имеющимися методиками (Ермаков, Долгов, 1979; Калюжный, 1982; Рёддер, 1987; Мельников и др., 2008). Отнесение ФВ к генетическим типам проводилось в соответствии с установленными критериями (Ермаков, Долгов, 1979; Калюжный, 1982; Bodnar, Vityk, 1994; Мельников и др., 2008). Коэффициент наполнения (КН) рассчитан при условии, что ФВ имеют уплощенную форму, по формуле: $\mathrm{KH}=\mathrm{Sж} / \mathrm{S}$ в 100 , где $\mathrm{Sж} \mathrm{-} \mathrm{площадь}$ жидкой фазы, Sв - площадь вакуоли. Солевой состав растворов и их концентрацию определяли методом криометрии согласно экспериментальным данным (Борисенко, 1977). Плотность флюида и давление рассчитывали с помощью программы FLINCOR по системе П. Брауна и У. Лэмба (Brown, Lamb, 1989). КР-спектроскопия выполнена в ИГМ СО РАН при поддержке гранта РФФИ № 13-05-90703 на дисперсионном Раманмикроскопе Lab Ram HR в широком спектральном диапазоне 150-3800 cм-1, с возбуждающей линией 514 нм Не-Ne лазера и спектральной шириной щели $2 \mathrm{~cm}^{-1}$ (аналитик Е. Е. Колова). Разложение сложных контуров проведено с помощью программы Origin 7.5.

\section{ГЕОЛОГИЧЕСКОЕ СТРОЕНИЕ ШТОКОВОГО РУДНОГО ПОЛЯ И ВЕЩЕСТВЕННЫЙ СОСТАВ РУД}

Штоковое рудное поле (рис. 1) располагается в пределах Вилигинского террейна - фрагмента задугового бассейна пермско-раннеюрского возраста (Геодинамика..., 2006). Оно приурочено к купольной структуре, в ядре которой обнажен шток позднеюрских (U-Pb возраст 147.4 \pm 1.6 млн лет, М. И. Зименко, 2014 г.) гранитов пло- щадью 2.2 км². Шток сложен среднезернистыми биотитовыми гранитами ильменитовой серии, относящимися к басугуньинскому интрузивному комплексу (Волков и др., 2013). Вмещающие шток породы представлены ороговикованными алевролитами и песчаниками среднего и верхнего триаса, которые в экзоконтактовой зоне интрузии изменены до кордиерит-биотитовых роговиков. В юго-восточной части гранитного штока была выявлена (Кузнецов и др., 2011) зона грейзенизации и сульфидизации протяженностью до 200 м и мощностью до 5 м, среди которой распространены кварцевые и сульфидно-кварцевые прожилки и реже жилы. И граниты, и осадочные породы прорваны редкими дайками риолитов, андезитов и базальтов. Разрывные нарушения имеют северовосточное и субмеридиональное простирание.

Все установленные на данный момент жилы, жильно-прожилковые и минерализованные зоны (см. рис. 1) имеют северо-восточное и субмеридиональное простирание, за редким исключением - северо-западное. Мощность рудных образований 0.2-0.3 м, редко до $1.5 \mathrm{M}$, протяженность до 2300-500 м.

В пределах рудного поля выделяются два участка: «Штоковый» и «Галлюцинация». Жилы, жильно-прожилковые и минерализованные зоны участка «Штоковый» имеют крутое $\left(60-70^{\circ}\right)$ падение и вмещаются гранитами; рудные образования участка «Галлюцинация» локализуются в ороговикованных осадочных толщах и имеют пологое залегание. Содержания золота в рудах составляют 1-17 г/т, серебра - 5-40 г/т. Характерны повышенные концентрации As (>1\%), Bi (до $0.02 \%$ ), W ( до 0.1\%). Жилы участка «Галлюцинация» отличаются повышенными содержаниями $\mathrm{Ag}$ (до 1215 г/т) и $\mathrm{Pb}$ (до 0.1\%).

Среди текстур руд преобладают жильные, вкрапленные и прожилково-вкрапленные (рис. 2). В подчиненном количестве встречаются брекчиевые текстуры, где среди обломков установлены кварц из прожилков ранней генерации, граниты и осадочные породы, которые сцементированы кварцевым и кварц-гидрослюдистым материалом. Рудная минерализация в основном сосредоточена в кварцевых прожилках ранней генерации и их обломках, а также в виде вкрапленной сульфидной минерализации в позднем халцедоновидном кварце.

В составе рудной минерализации Штокового рудного поля установлены 42 минеральных вида (табл. 1). Руды относятся к малосульфидным (количество сульфидов не более 2-3\%). Жильные минералы представлены кварцем, карбонатом, гидрослюдой, полевым шпатом, мусковитом, хлоритом и актинолитом. Рудные минералы арсенопирит, пирит, сфалерит, халькопирит, галенит, пирротин, теллуриды висмута, самород- 
ное золото и минералы серебра (Ag-содержащие блеклые руды и сульфосоли, акантит и самородное серебро). Среди гипергенных - оксиды $\mathrm{Fe}, \mathrm{Mn}$ и $\mathrm{Pb}$, гидроксиды Fe.

Все известные к данному моменту прожилки и жилы сложены кварцем, который по морфологическим признакам и минеральным взаимоотношениям разделен на три генерации: кварц I - неравномерно-зернистый, с включениями сульфидов, блеклой руды, сульфосолей, самородного золота I и серебра. Размер кристаллов в поперечнике 0.1-0.3 мм. Отмечается его высокая флюидонасыщенность. Вдоль контакта прожилков и по зонам роста крупных кристаллов развита тонкочешуйчатая гидрослюда; кварц II прозрачные (вплоть до горного хрусталя) кристаллы размером до 4 мм. Совместно с карбонатом образует просечки и линзы мощностью до 1.5 мм. В кварце II в свободном состоянии установлены включения самородного золота II, золотоносного арсенопирита и реликты минералов, полностью замещенных лимонитом; наиболее поздний - халцедоновидный - кварц III образует тонкие прожилки, секущие ранний кварц. Содержит включения самородного золота III и пирита.

Главный рудный минерал арсенопирит. Установлены две его генерации: арсенопирит I крупнокристаллический, с включениями теллуридов висмута (рис. 3,$3 ; 4$, в), самородного золота I (рис. 4, a), блеклой руды (рис. 3, б), галенита (рис. 3, ж), халькопирита (рис. 3, в), пирита (рис. 3, г), а также сульфосолей, пирротина и сфалерита. Содержание As в нем 29-33 ат. \%. Отношение S/As - 1.01-1.23.

Арсенопирит II образует скопления катаклазированных кристаллов (размером до 4 мм) (рис. 3, $)$ ). Развивается по периферии и по трещинам в сфалерите I (рис. 3, e).

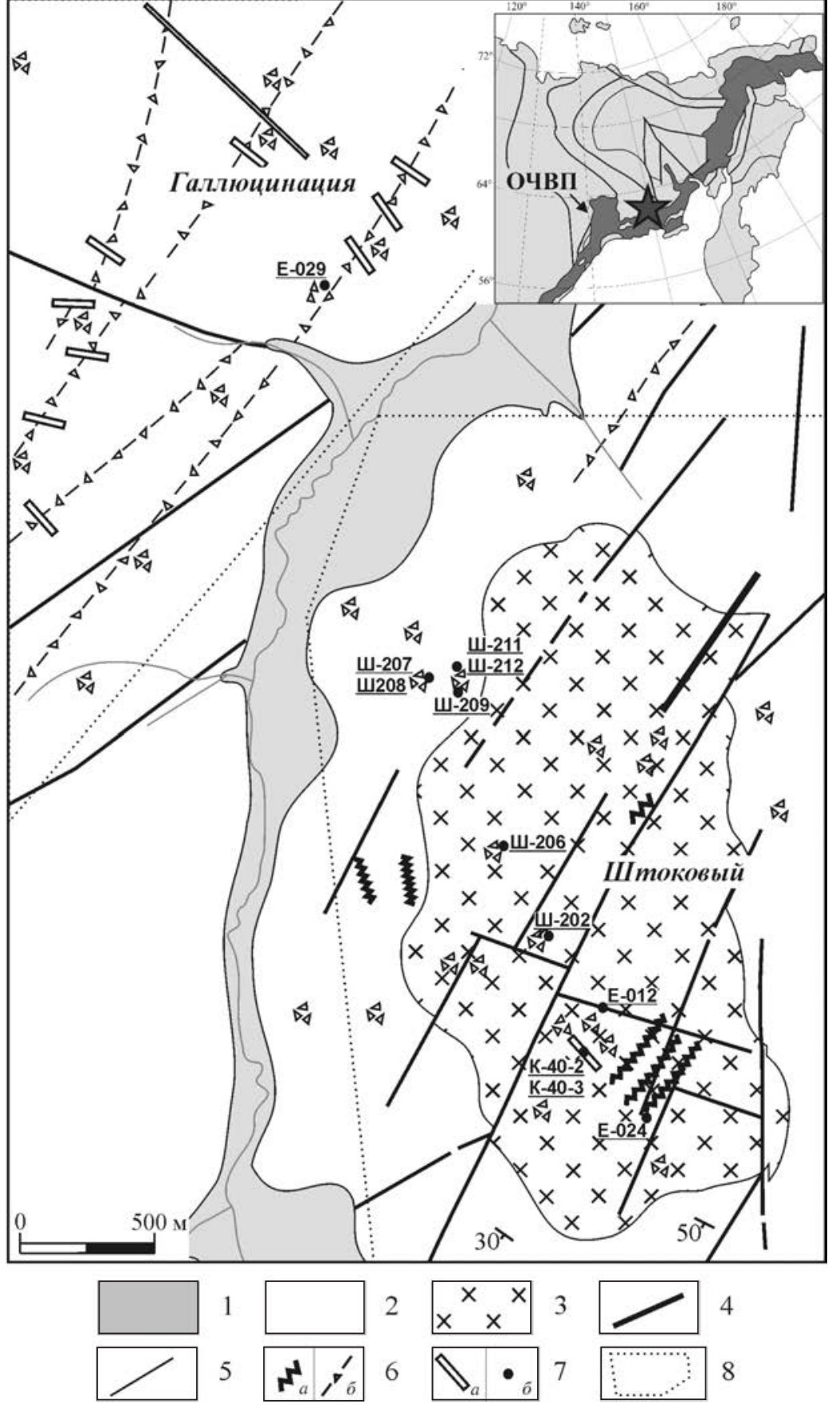

Рuc. 1. Схема геологического строения Штокового рудного поля (Кузнецов и др., 2011 с данными ООО ДГРП, 2013 г.): 1 - четвертичные аллювиальные отложения; 2 - ороговикованные триасовые алевролиты и песчаники. Элементы залегания (по Ю. Г. Кобылянскому, 1962 г.); 3 - граниты; 4 - дайки риолитов и базальтов; 5 - разломы; 6 - кварцевые и сульфидно-кварцевые жилы $(a)$ и жильные зоны (б); 7 - горные выработки 2013 г. (a), места отбора изученных образцов и их номера (б); 8 - лицензионные границы участков

Fig. 1. Scheme of the Shtokovoye ore field geological structure (Kuznetsov et al., 2011, with data from DGRP LLC, 2013): 1 - Quaternary alluvial deposits; 2 - hornfelsed Triassic siltstones and sandstones. Bedding elements after (Kobylyansky, 1962); 3 - granites; 4 - dikes of rhyolites and basalts; 5 - faults; 6 - quartz and sulfide-quartz lodes (a) and lode zones (б); 7 - mine workings, 2013 (a), spots of collecting the studied samples and their numbers (б); 8 - boundaries of licensed sites 

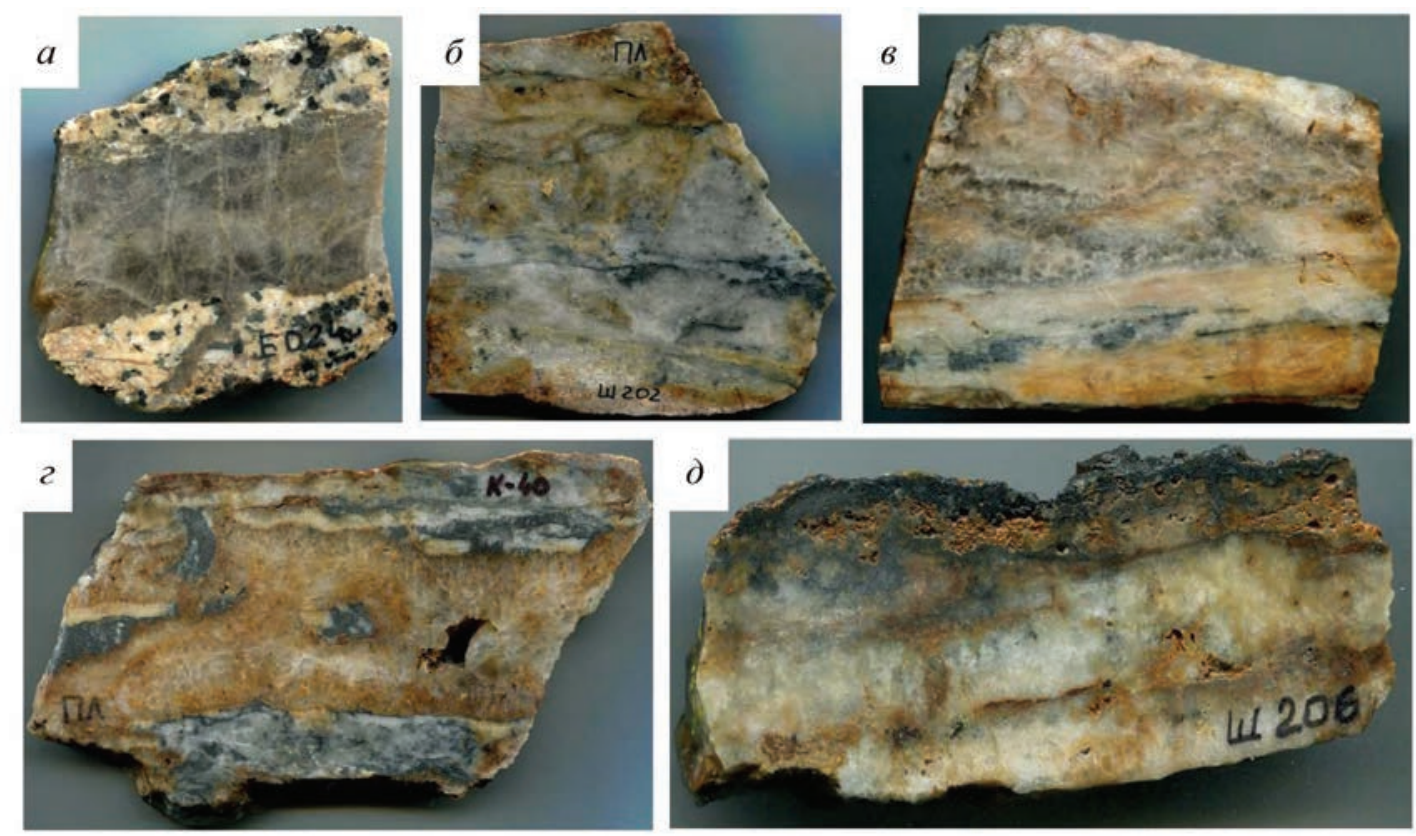

Puc. 2. Текстуры руд Штокового рудного поля: прожилковая (a); жильная и вкрапленная (б); жильная, прожилково-вкрапленная (кварц-сульфидный прожилок раннего кварца обрастает кварцем второй генерации) (в); брекчиевая, жильная (2); корки и натечные формы оксидов марганца ( $\partial$ )

Fig. 2. Ore textures of the Shtokovoye ore field: veined (a); loded and disseminated ( $\sigma)$; loded, veined-disseminated (quartz-sulfide vein of early quartz is rimmed with the second generation quartz) (B); brecciated, veined (2); crusts and sinters of $\mathrm{MnOx}(\partial)$

Таблица 1. Минеральный состав руд Штокового рудного поля Table 1. Mineralogy of the Shtokovoye ore field

\begin{tabular}{|c|c|c|c|}
\hline Группы минералов & Главные & Второстепенные & Редко встречающиеся \\
\hline $\begin{array}{l}\text { Жильно-метасо- } \\
\text { матические }\end{array}$ & $\begin{array}{l}\text { Кварц } \\
\text { Полевой шпат }\end{array}$ & $\begin{array}{l}\text { Карбонат } \\
\text { Гидрослюда } \\
\text { Рутил } \\
\text { Мусковит } \\
\text { Серицит } \\
\text { Хлорит } \\
\text { Актинолит } \\
\text { Халцедон } \\
\end{array}$ & $\begin{array}{l}\text { Апатит } \\
\text { Турмалин } \\
\text { Магнетит } \\
\text { Титаномагнетит } \\
\text { Ильменит } \\
\text { Гематит } \\
\text { Углеродистое вещество } \\
\text { Циркон } \\
\end{array}$ \\
\hline Рудные & Арсенопирит & $\begin{array}{l}\text { Сфалерит } \\
\text { Пирит } \\
\text { Акантит } \\
\text { Аргентотетраэдрит }\end{array}$ & $\begin{array}{l}\text { Марказит } \\
\text { Теллуриды Bi } \\
\text { Диафорит } \\
\text { Пираргирит } \\
\text { Галенит } \\
\text { Пирротин } \\
\text { Халькопирит } \\
\text { Самородный Bi } \\
\text { Самородное Au } \\
\text { Самородное Ag }\end{array}$ \\
\hline Гипергенные & Лимонит & $\begin{array}{l}\text { Оксиды Mn } \\
\text { Скородит }\end{array}$ & $\begin{array}{l}\text { Оксиды Pb } \\
\text { Гидроксиды Fe } \\
\text { Лейкоксен }\end{array}$ \\
\hline
\end{tabular}

Содержание As в нем 31-35 ат. \%. По сравнению с арсенопиритом I содержит меньше серы (17.77-18.7 мас.\%) и больше мышьяка (45.7647.26 мас.\%; табл. 2). Отношение S/As - 0.9-0.95. В соответствии с работой (Тюкова, Ворошин, 2007) такое соотношение S/As указывает на то, что арсенопирит не претерпел воздействий пострудного метаморфического процесса, в отличие, например, от арсенопирита в рудах Игуменовского или Родионовского месторождения, где этот коэффициент варьирует от 1.1 до 1.5 (Волков и др., 2011). 

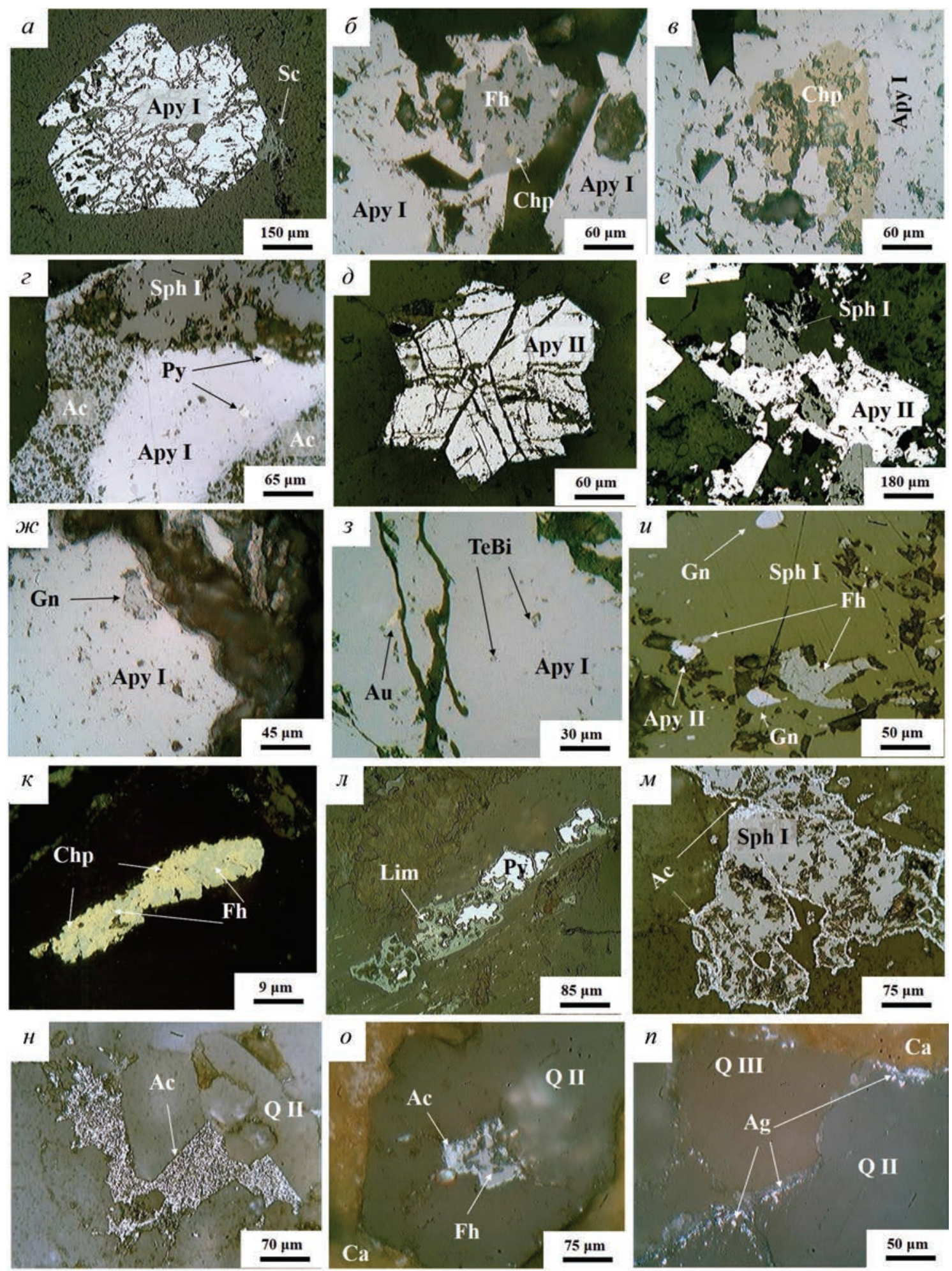

Puc. 3. Взаимоотношения рудных минералов: $a$ - обособление катаклазированных кристаллов арсенопирита I, частично замещенных скородитом; $\sigma$ - срастание арсенопирита I и блеклой руды. В блеклой руде включение халькопирита; в - включение халькопирита в арсенопирите I; 2 - срастание сфалерита I, акантита и арсенопирита I (в арсенопирите включение пирита); $\partial$ - звездчатые обособления арсенопирита II; $e$ - пересечение сфалерита I арсенопиритом II; ж- включение галенита в арсенопирите I; з - микровключения самородного золота и теллуридов висмута в арсенопирите I; $u$ - включение галенита, арсенопирита II и блеклой руды в сфалерите I; $\kappa$ - срастание халькопирита и блеклой руды; $л$ - пирит частично замещен лимонитом; $⿻$ - обрастание сфалерита I акантитом; $\boldsymbol{\mu}$ - отложение акантита в интерстициях кварца II; $o$ - включение блеклой руды в кварцкарбонатном прожилке. По краю блеклой руды развивается акантит; $n$ - каплевидные микровключения самородного серебра на контакте кварц-карбонатного агрегата и кварца III 
Fig. 3. Ore mineral relations: $a$ - segregation of cataclastic arsenopyrite crystals partly replaced by scorodite; $\sigma$ - intergrowth of arsenopyrite I and fahlore, the latter including chalcopyrite; 8 - chalcopyrite inclusion in arsenopyrite I; 2 - intergrowth of sphalerite I, acantite, and arsenopyrite I, the latter including pyrite; $\partial$ - stellate segregations of arsenopyrite II; $e$-arsenopyrite II intersecting sphalerite I; $\nsim$-galena inclusion in arsenopyrite I; 3 - microinclusions of native gold and bismuth tellurides in arsenopyrite I; $u$-inclusions of galena, arsenopyrite II and fahlore in sphalerite I; $\kappa$ - intergrowth of chalcopyrite and fahlore; $\Omega$ - pyrite partly replaced with limonite; $\mu$ - sphalerite I rimmed with acantite; $\mu$ - acantite deposition in quartz II interstitions; $O$ - fahlore inclusion in a quartz-carbonate vein, with acantite developing on the edge of fahlore; $n$-teardrop microinclusions of native silver at the contact of the quartz-carbonate aggregate and quartz III

\section{Таблица 2. Химический состав сульфидов Штокового рудного поля по результатам микрозондового} анализа

Table 2. Chemical composition of sulfides from the Shtokovoye ore field by microprobe analysis

\begin{tabular}{|c|c|c|c|c|c|c|c|c|c|c|c|c|}
\hline $\begin{array}{l}\text { № } \\
\Pi / \Pi\end{array}$ & $\begin{array}{l}\text { Номер } \\
\text { образца }\end{array}$ & \multicolumn{5}{|c|}{ Весовые концентрации, \% } & Сумма & \multicolumn{5}{|c|}{ Формульные коэффициенты } \\
\hline \multicolumn{13}{|c|}{ Галенит $-\boldsymbol{P b}_{1.00} S_{0.99}$} \\
\hline & & $\mathrm{Fe}$ & $\mathrm{Pb}$ & As & $\mathrm{Ag}$ & S & Сумма & $\mathrm{Fe}$ & $\mathrm{Pb}$ & As & $\mathrm{Ag}$ & $\mathrm{S}$ \\
\hline 1 & K-40-2 & - & 86.65 & - & - & 12.96 & 99.61 & - & 1.02 & - & - & 0.98 \\
\hline 2 & $\mathrm{~K}-40-2$ & - & 85.40 & - & - & 13.10 & 98.50 & - & 1.00 & - & - & 1.00 \\
\hline 3 & Ш-206-2 & - & 84.15 & - & - & 12.70 & 96.85 & - & 1.01 & - & - & 0.99 \\
\hline \multicolumn{13}{|c|}{ Пирит $-F e_{1.00} S_{2.00}$} \\
\hline 4 & K-40-3 & 45.75 & - & - & - & 52.39 & 98.14 & 1.00 & - & - & - & 2.00 \\
\hline 5 & Ш-207 & 45.99 & - & - & - & 52.53 & 98.52 & 1.00 & - & - & - & 2.00 \\
\hline 6 & Ш-207 & 46.47 & - & - & - & 52.73 & 99.20 & 1.01 & - & - & - & 1.99 \\
\hline \multicolumn{13}{|c|}{ Арсенопирит I-Fe $e_{1.01} A s_{0.92} S_{1.07}$} \\
\hline 7 & K-40-2 & 35.40 & - & 42.55 & - & 21.80 & 99.75 & 1.01 & - & 0.91 & - & 1.08 \\
\hline 8 & K-40-2 & 35.24 & - & 43.34 & - & 21.46 & 100.04 & 1.01 & - & 0.92 & - & 1.07 \\
\hline 9 & $\mathrm{~K}-40-2$ & 34.92 & - & 43.73 & - & 21.12 & 99.77 & 1.00 & - & 0.94 & - & 1.06 \\
\hline 10 & K-40-2 & 34.79 & - & 43.20 & - & 21.34 & 99.33 & 1.00 & - & 0.93 & - & 1.07 \\
\hline \multicolumn{13}{|c|}{ Aрсенопирит II $-\mathrm{Fe}_{1.0 I} A s_{1.03} S_{0.96}$} \\
\hline 11 & Ш-202-3 & 33.69 & - & 46.43 & - & 17.86 & 97.98 & 1.02 & - & 1.04 & - & 0.94 \\
\hline 12 & Ш-202-3 & 34.22 & - & 46.01 & - & 18.69 & 98.92 & 1.02 & - & 1.02 & - & 0.97 \\
\hline 13 & Ш-202-3 & 34.13 & - & 45.98 & - & 18.45 & 98.56 & 1.02 & - & 1.02 & - & 0.96 \\
\hline 14 & Ш-202-3 & 33.90 & - & 47.26 & - & 17.77 & 98.93 & 1.02 & - & 1.06 & - & 0.93 \\
\hline \multicolumn{13}{|c|}{ Акантит $\mathrm{Ag}_{2.05} \mathrm{~S}_{0.95}$} \\
\hline 15 & Ш-206-1 & - & - & - & 86.77 & 14.17 & 100.94 & - & - & - & 1.94 & 1.06 \\
\hline 16 & Ш-206-1 & - & - & - & 88.13 & 11.61 & 99.74 & - & - & - & 2.08 & 0.92 \\
\hline 17 & K-40-2 & - & - & - & 90.16 & 8.47 & 98.63 & - & - & - & 2.28 & 0.72 \\
\hline 18 & Ш-206-2 & - & - & - & 85.25 & 13.03 & 98.28 & - & - & - & 1.98 & 1.02 \\
\hline 19 & Ш-206-2 & - & - & - & 85.41 & 13.22 & 98.64 & - & - & - & 1.97 & 1.03 \\
\hline \multicolumn{13}{|c|}{ Пирротин $-\mathrm{Fe}_{7.0} \boldsymbol{S}_{7.93}$} \\
\hline 20 & K-40-3 & 59.08 & - & - & - & 38.31 & 97.39 & 7.04 & - & - & - & 7.96 \\
\hline 21 & K-40-3 & 59.69 & - & - & - & 38.38 & 98.07 & 7.08 & - & - & - & 7.92 \\
\hline 22 & K-40-3 & 59.71 & - & - & - & 38.35 & 98.06 & 7.08 & - & - & - & 7.92 \\
\hline \multicolumn{13}{|c|}{ Сфалерит } \\
\hline & & $\mathrm{Fe}$ & $\mathrm{Zn}$ & $\mathrm{Cu}$ & $\mathrm{Mn}$ & $\mathrm{S}$ & Сумма & $\mathrm{Fe}$ & $\mathrm{Zn}$ & $\mathrm{Cu}$ & $\mathrm{Mn}$ & $\mathrm{S}$ \\
\hline 23 & K-40-2 & 10.16 & 50.32 & 4.84 & 0.80 & 34.02 & 100.14 & 0.17 & 0.73 & 0.07 & 0.01 & 1.01 \\
\hline 24 & K-40-2 & 6.66 & 58.60 & 0.00 & 0.81 & 33.80 & 99.87 & 0.11 & 0.86 & 0.00 & 0.01 & 1.01 \\
\hline 25 & K-40-3 & 10.99 & 49.02 & 4.20 & 1.46 & 33.12 & 98.79 & 0.17 & 0.73 & 0.07 & 0.01 & 1.01 \\
\hline 26 & Ш-206-1 & 9.83 & 53.90 & 0.00 & 2.37 & 33.82 & 99.92 & 0.11 & 0.86 & 0.00 & 0.01 & 1.01 \\
\hline
\end{tabular}


Один из наиболее распространенных минералов - сфалерит. Выделены две его генерации: сфалерит I - ксеноморфный, темно-бурый, непрозрачный, образует агрегаты размером до 1.3 мм, в составе установлены примесь железа от 6.22 до $12.07 \%$ и марганца от 0.8 до $4.5 \%$ (см. табл. 2). Отличительной чертой является наличие эмульсионной вкрапленности халькопирита. Реже содержит включения галенита, арсенопирита и блеклой руды (рис. $3, u)$. Обрастает и пересекается акантитом и арсенопиритом II (см. рис. 3, е, м). Сфалерит II - ксеноморфный, прозрачный, без эмульсии халькопирита, с размером выделений до 0.24 мм, ассоциирует с арсенопиритом.
Пирит на площади Штокового рудного поля встречается в двух генерациях: пирит I - ксеноморфного и идиоморфного облика. Катаклазированный. Срастается со сфалеритом I, халькопиритом и арсенопиритом I. Содержит включения галенита. По более крупным скоплениям пирита I развивается марказит. Частично или полностью замещен лимонитом (рис. $3, \pi$ ). Размер кристаллов от 0.01 до 1 мм, скопления - до 5 мм. Пирит II - мелкокристаллический, образует псевдоморфозы по гематиту. Размер от 0.001 до 0.05 мм.

Халькопирит образует включения в арсенопирите I (рис. 3, в), блеклой руде (рис. 3, б) и эмульсионную вкрапленность в сфалерите I. Размеры включений от 0.01 до 0.18 мм. Установлены
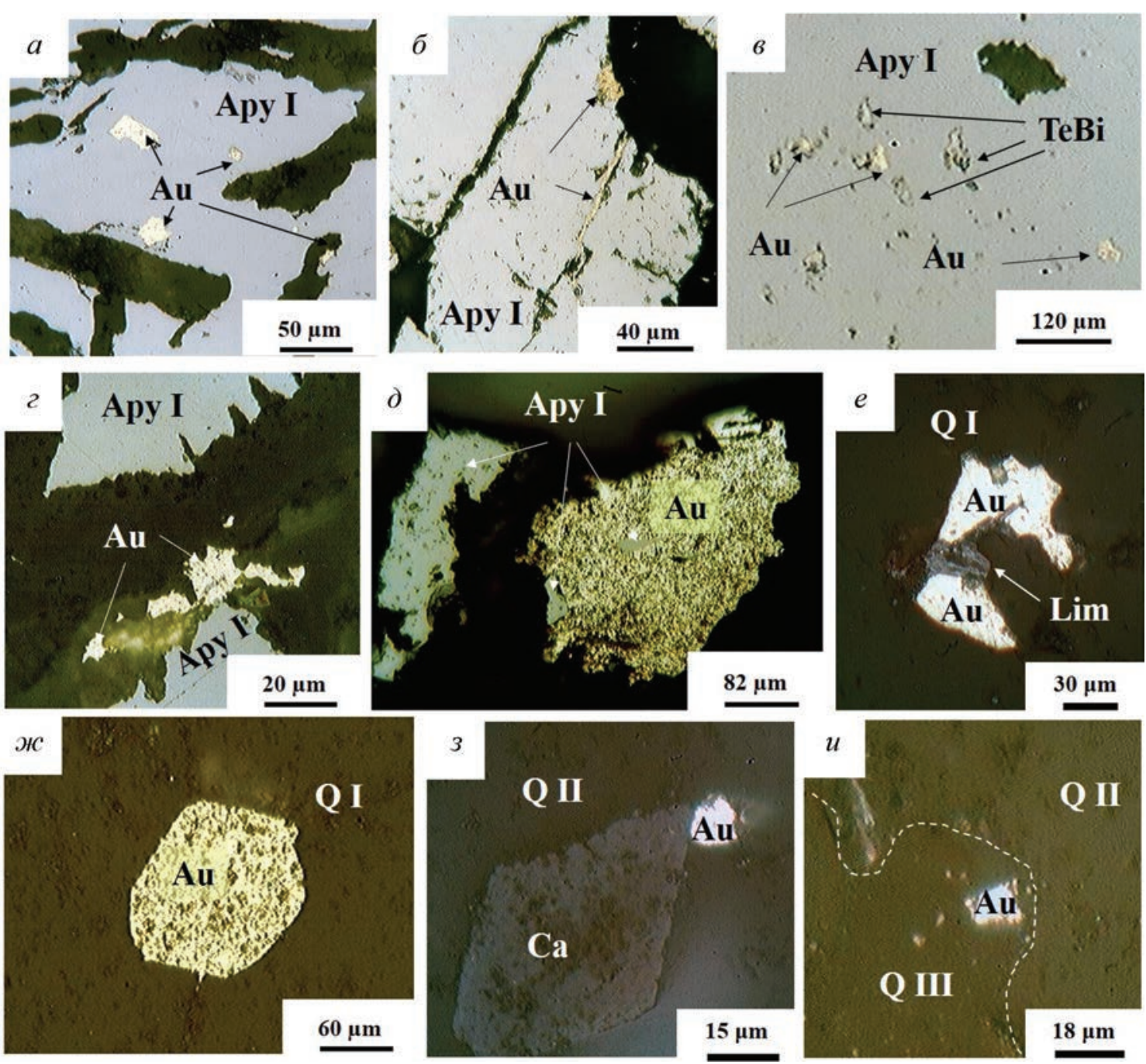

Puc. 4. Формы выделений самородного золота: : $a$ - в виде включений в арсенопирите I; $\sigma$ - отложение по трещинам катаклаза в арсенопирите I; в - в арсенопирите I в ассоциации с теллуридами висмута; 2 - в срастании с арсенопиритом I; $\partial$ - включение арсенопирита I в самородном золоте; $e$ - самородное золото в «рубашке» из лимонита; ж- включение самородного золота в кварце I; з - на контакте карбоната и кварца II; $u$ на контакте кварца II и кварца III

Fig. 4. Forms of native gold separations: $a$-inclusions with arsenopyrite I; $\sigma$ - in the cataclastic fractures in the arsenopyrite I; 6 - in arsenopyrite I in association with Bi-tellurides; 2 - intergrowth with arsenopyrite I; $\partial-$ arsenopyrite I inclusions in native gold; $e$ - native gold in a limonite "envelope"; $⿻$ - native gold in quartz; 3 - at the contact of quartz II and carbonate; $u-$ at the contact of quartz II and quartz III 
срастания с галенитом, пиритом, сфалеритом I и блеклой рудой (рис. $3, \kappa)$.

Теллуриды Ві встречаются редко, образуя тонкую (не более 0.04 мм) вкрапленность в арсенопирите I, заполняя микропустоты в нем (см. рис. 3,$3 ; 4$, в). Находятся в пространственной ассоциации с самородным золотом.

Самородное золото отлагается в виде: а) включений в арсенопирите I, где пространственно ассоциирует с теллуридами висмута (рис. 4, $a-2) ;$ б) в свободном состоянии в кварце I (рис. 4 , $ж-u$ ), иногда содержит включения арсенопирита I (рис. $4, \partial)$; в) моновключений в кварце II в срастании с карбонатом (рис. $4, u$ ). Нередко по периферии частиц золота видны следы оксидов $\mathrm{Fe}$ (лимонита) (рис. $4, e) ;$ г) микровключений в кварце III. Таким образом, выделяются три генерации самородного золота: а, б - I генерации, в II генерации, г - III. Пробность всего изученного самородного золота Штокового рудного поля варьирует от 425 до $870 \%$, со средним значением $798 \%$.

Самородное серебро отлагается в свободном состоянии на контакте кварц-карбонатного агрегата и кварца III (рис. $3, n$ ).
Акантит отлагается в интерстициях кварца II (рис. 3,, ), а также по периферии блеклых руд (рис. $3, o$ ) и сфалерита I (рис. 3, м). Срастается с арсенопиритом I (рис. 3, 2), оксидами Mn и сфалеритом I. Размер обособлений до 0.4 мм.

Блеклая руда и сульфосоли Ag развиваются по микротрещинам в арсенопирите I (рис. 3,6 ) и образуют включения в сфалерите I (рис. $3, u$ ). Помимо этого срастаются с арсенопиритом II, халькопиритом, пирротином и галенитом. В редких случаях по периферии обрастает акантитом. Размер включений от 0.001 до 0.17 мм. По результатам микрозондового анализа среди блеклых руд установлен аргентотетраэдрит, а среди сульфосолей - пираргирит и диафорит (табл. 3).

На основании изучения пространственновременных соотношений минералов и минеральных парагенезисов установлен полистадийный характер процесса формирования руд (табл. 4), который проявился в пространственном совмещении золото-кварцевого (мезотермального) и серебро-сульфосольно-акантитового оруденения, завершившегося образованием прожилков халцедоновидного кварца с рудной ассоциацией эпитермального генезиса.

Таблица 3. Химический состав минералов группы сульфосолей Штокового рудного поля по результатам микрозондовых анализов

Table 3. Chemical composition of sulfosalts of the Shtokovoye ore field by microprobe analyses

\begin{tabular}{|c|c|c|c|c|c|c|c|c|c|c|c|c|c|c|}
\hline $\begin{array}{l}\text { № } \\
\text { п/п }\end{array}$ & $\begin{array}{l}\text { Номер } \\
\text { образца }\end{array}$ & \multicolumn{6}{|c|}{ Весовые концентрации, \% } & Сумма & \multicolumn{6}{|c|}{ Формульные коэффициенты } \\
\hline \multicolumn{15}{|c|}{ Диафорит - $A g_{3,22} P b_{1,84} F e_{0,12} C u_{0,03} S b_{2,93} S_{7,85}$} \\
\hline & & $\mathrm{Pb}$ & $\mathrm{Fe}$ & $\mathrm{Cu}$ & $\mathrm{Ag}$ & $\mathrm{Sb}$ & $\mathrm{S}$ & Сумма & $\mathrm{Pb}$ & $\mathrm{Fe}$ & $\mathrm{Cu}$ & $\mathrm{Ag}$ & $\mathrm{Sb}$ & S \\
\hline 1 & Ш-206-2 & 26.66 & 0.64 & 0.52 & 25.5 & 26.45 & 18.37 & 98.14 & 1.75 & 0.16 & 0.11 & 3.22 & 2.96 & 7.80 \\
\hline 2 & Ш-206-2 & 28.72 & \begin{tabular}{|l|}
0.67 \\
\end{tabular} & - & 24.98 & 25.94 & 18.47 & 98.77 & 1.89 & 0.16 & 0.00 & 3.16 & 2.91 & 7.87 \\
\hline 3 & Ш-206-2 & 28.64 & 0.68 & - & 24.65 & 26.26 & 18.47 & 98.71 & 1.89 & 0.17 & 0.00 & 3.12 & 2.95 & 7.87 \\
\hline 4 & Ш-206-2 & 27.72 & 0.00 & - & 24.61 & 25.84 & 18.42 & 98.59 & 1,83 & 0.00 & 0.00 & 3.38 & 2.91 & 7.86 \\
\hline \multicolumn{15}{|c|}{ Пираргирит $-\mathrm{Ag}_{2,91} \mathrm{Cu}_{0,18} \mathrm{Fe}_{0,09} \mathrm{Zn}_{0,08} \mathrm{Sb}_{0,91} \mathrm{~S}_{2,78}$} \\
\hline & & $\mathrm{Zn}$ & $\mathrm{Fe}$ & $\mathrm{Cu}$ & $\mathrm{Ag}$ & $\mathrm{Sb}$ & $\mathrm{S}$ & Сумма & $\mathrm{Zn}$ & $\mathrm{Fe}$ & $\mathrm{Cu}$ & $\mathrm{Ag}$ & $\mathrm{Sb}$ & $\mathrm{S}$ \\
\hline 7 & K-40-3 & 1.11 & - & - & 60.77 & 21.28 & 17.08 & 100.23 & 0.09 & 0.00 & 0.00 & 3.06 & 0.95 & 2.90 \\
\hline 8 & K-40-3 & 1.48 & - & - & 60.95 & 21.33 & 16.98 & 100.74 & 0.12 & 0.00 & 0.00 & 3.06 & 0.95 & 2.87 \\
\hline 9 & K-40-3 & 1.1 & - & - & 60.41 & 21.49 & 17.04 & 100.04 & 0.09 & 0.00 & 0.00 & 3.05 & 0.96 & 2.90 \\
\hline 10 & Ш-206-1 & - & 3.79 & 8.51 & 50.78 & 18.09 & 16.68 & 97.85 & 0.00 & 0.35 & 0.70 & 2.46 & 0.78 & 2.46 \\
\hline \multicolumn{15}{|c|}{ Aргенттотетраэдрит - $\left(\mathrm{Ag}_{6,97} \mathrm{Cu}_{3,96}\right)_{10,93}\left(\mathrm{Fe}_{1,85} \mathrm{Zn}_{0,22}\right)_{2,07} \mathrm{Sb}_{3,97} \mathrm{~S}_{12,24}$} \\
\hline & & $\mathrm{Zn}$ & $\mathrm{Fe}$ & $\mathrm{Cu}$ & $\mathrm{Ag}$ & $\mathrm{Sb}$ & $\mathrm{S}$ & Сумма & $\mathrm{Zn}$ & $\mathrm{Fe}$ & $\mathrm{Cu}$ & Ag & $\mathrm{Sb}$ & $\mathrm{S}$ \\
\hline 11 & Ш-206-1 & 1.06 & 5.27 & 13.01 & 35.82 & 24.85 & 20.03 & 100.04 & 0.32 & 1.85 & 4.02 & 6.52 & 4.01 & 12.27 \\
\hline 12 & Ш-206-1 & 0.70 & 5.18 & 12.23 & 37.86 & 23.96 & 19.16 & 98.99 & 0.22 & 1.87 & 3.95 & 7.07 & 3,95 & 12.03 \\
\hline 13 & Ш-206-1 & 0.60 & 4.87 & 9.10 & 42.83 & 23.20 & 19.24 & 99.84 & 0.19 & 1.77 & 3.87 & 8.07 & 3,87 & 12.19 \\
\hline 14 & Ш-206-1 & 0.64 & 5.11 & 12.70 & 35.92 & 24,50 & 19.92 & 98.79 & 0.19 & 1.82 & 4.01 & 6.63 & 4.01 & 12.37 \\
\hline 15 & Ш-206-2 & - & 5.79 & 13.0 & 34.24 & 25.29 & 20.27 & 98.59 & - & 2.05 & 4.05 & 6.28 & 4.11 & 12.51 \\
\hline 16 & Ш-206-2 & - & 5.63 & 13.36 & 34.72 & 25.22 & 20.28 & 99.22 & - & 1.99 & 4.14 & 6.34 & 4.08 & 12.46 \\
\hline
\end{tabular}


Таблица 4. Этапы, стадии минералообразования и минеральные ассоциации Штокового рудного поля Table 4. Mineral associations and mineralization stages of the Shtokovoye ore field

\begin{tabular}{|l|l|l|}
\hline \multicolumn{1}{|c|}{ Этап } & \multicolumn{1}{|c|}{ Стадия, ассоциация } & \multicolumn{1}{|c|}{ Минералы } \\
\hline $\begin{array}{l}\text { I. Дорудный гидро- } \\
\text { термальный }\end{array}$ & Пирит-пирротиновая & Полевой шпат, пирит I, пирротин \\
\hline $\begin{array}{l}\text { II. Рудный гидро- } \\
\text { термальный } \\
\text { плутоногенный }\end{array}$ & Золото-арсенопиритовая & $\begin{array}{l}\text { Кварц I, арсенопирит I, сфалерит I, самородное } \\
\text { золото I }\end{array}$ \\
\cline { 2 - 3 } & $\begin{array}{l}\text { Золото-теллуридно-висму- } \\
\text { товая }\end{array}$ & $\begin{array}{l}\text { Кварц II, карбонат, арсенопирит II, сфалерит II, } \\
\text { галенит, теллуриды Вi, самородное золото II, } \\
\text { самородный Вi, сульфосоли Ag }\end{array}$ \\
\hline $\begin{array}{l}\text { III. Рудный гидро- } \\
\text { термальный } \\
\text { вулканогенный }\end{array}$ & $\begin{array}{l}\text { Серебро-золото-акантито- } \\
\text { вая }\end{array}$ & $\begin{array}{l}\text { Кварц III, серицит, пирит II, блеклая руда, } \\
\text { самородное золото III (кюстелит), самородное } \\
\text { серебро, акантит }\end{array}$ \\
\hline IV. Гипергенный & Оксиды Fе и Мп \\
\hline
\end{tabular}

\section{ИССЛЕДОВАНИЕ ФЛЮИДНЫХ ВКЛЮЧЕНИЙ}

Термометрией охвачено 90 флюидных включений в кварце I и II генераций, слагающего прожилки и жилы участков «Штоковый» и «Галлюцинация». Халцедоновидный кварц (кварц III генерации) термобарогеохимическим анализом (ТБГ) не охвачен вследствие инструментальных ограничений методов.

Размер ФВ колеблется от 3 до 20 мкм. Большая их часть (66\%) имеет размер от 5 до 10 мкм. При комнатной температуре по фазовому составу выделяются три типа ФВ: 1) L - газово-жидкие; 2) LC включения, содержащие фазы водного раствора и газообразной $\mathrm{CO}_{2}$; 3) $\mathrm{C}$ - газовые, углекислотные (табл. 5, рис. 5). В большинстве случаев ФВ разных типов и с разным соотношением фаз локализуются в едином пространстве, имеют генеральную динию расположения и могут считаться сингенетичными.

При криометрии во ФВ LC-типа и С-типа плавление газовой фазы происходит при температурах от -59.1 до $-56.1^{\circ} \mathrm{C}$, гомогенизация - от 8 до $24^{\circ} \mathrm{C}$, а плавление газогидратов - от 5.8 до $10.1^{\circ} \mathrm{C}$ (см. табл. 5). Такое поведение газовых составляющих ФВ при охлаждении указывает на наличие $\mathrm{CO}_{2}$ разной плотности и значительной примеси других газов. КР-спектрометрией (n = 10) в составе газовых фаз установлены $\mathrm{CO}_{2}, \mathrm{~N}_{2}$, $\mathrm{HS}^{-}, \mathrm{H}_{2} \mathrm{~S}, \mathrm{CH}_{4}$ (табл. 6, рис. 6). Доля $\mathrm{CO}_{2}$ в газовых смесях от 68.6 до $99.8 \%, \mathrm{CH}_{4}$ - от 0.1 до $28.2 \%$, $\mathrm{N}_{2}$ - от 0.1 до $16.5 \%$, a $\mathrm{HS}^{-}$и $\mathrm{H}_{2} \mathrm{~S}$ встречаются в разных вариациях, но их количество менее 1\%. В среднем соотношение между компонентами $\mathrm{CO}_{2} / \mathrm{CH}_{4} / \mathrm{N}_{2} / \mathrm{HS}^{-}+\mathrm{H}_{2} \mathrm{~S}=93 / 4 / 3 / 0.02$. Расчетная плотность $\mathrm{CO}_{2}$ (по Wang, 2010) обычно 0.2-0.4,

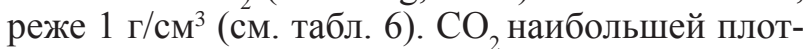
ности идентифицирована во ФВ С-типа. Газовая фаза ФB L-типа представлена $\mathrm{CO}_{2}$, плотность 0.2 г $/ \mathrm{cm}^{3}$ с незначительной примесью $\mathrm{CH}_{4}$.

Температуры эвтектики растворов во ФВ L-типа в кварце обоих участков варьируют от -28 до $-20^{\circ} \mathrm{C}$ (см. табл. 6), что характеризует растворы как $\mathrm{NaCl}$ с незначительной приместью ионов $\mathrm{K}, \mathrm{Mg}$ и $\mathrm{Fe}$.
Гомогенизация ФВ (см. табл. 6; рис. 7) в кварце участка «Штоковый» в целом происходит при температурах от 131 до $412^{\circ} \mathrm{C}$. ФB LC-типа гомогенизируются в температурном интервале 260$412^{\circ} \mathrm{C}$. ФB L-типа гомогенизируются при температурах от 131 до $318^{\circ} \mathrm{C}$. Единичные ФВ С-типа декрипитируют при температуре $200^{\circ} \mathrm{C}$. Распределение температур гомогенизации ФВ в кварце руд участка «Штоковый» имеет бимодальное распределение (см. рис. 7), наибольшее количество случаев приходится на интервалы 220-240 и $300-340^{\circ} \mathrm{C}$, причем в первый гомогенизируются только ФВ L-типа, во второй - преимущественно LC-типа.

В кварце участка «Галлюцинация» ФВ гомогенизируются при температуре от 152 до $383^{\circ} \mathrm{C}$. ФВ LC- и С-типов в единичных случаях гомогенизируются (С-типа декрипитируют) при температуре 152 и $227^{\circ} \mathrm{C}$, основная масса достигает гомогенного состояния в интервале от 243 до $383^{\circ} \mathrm{C}$. ФB L-типа гомогенизируются от 158 до $350^{\circ} \mathrm{C}$. Распределение температур гомогенизации ФВ в кварце участка «Галлюцинация», так же как и «Штокового», имеет бимодальное распределение (см. рис. 7) с интервалами $240-260$ и 300-340 ${ }^{\circ}$ С. Причем в первом интервале гомогенного состояния достигают преимущественно ФВ L-типа, во втором - LCтипа. Исходя из полученных данных, можно констатировать, что образование рудных тел изначально происходило из преимущественно углекислотного флюида и только когда температура в системе снизилась до $350^{\circ} \mathrm{C}$ на «Галлюцинации» и до $320^{\circ} \mathrm{C}$ на «Штоковом», флюид эволюционировал до водно-солевого состава.

Минимальная температура плавления последнего кристаллика льда во ФB L-типа участка «Штоковый» $-6.6^{\circ} \mathrm{C}$, участка «Галлюцинация» $-6^{\circ} \mathrm{C}$. Плавление фиксируется вплоть до температуры $-0.5^{\circ} \mathrm{C}$. Эти данные соответствуют концентрациям солей от 10 до 0.9 мас.\% экв. $\mathrm{NaCl}$. Динамика изменения солености на фоне снижения 
Таблица 5. Результаты микротермометрических исследований флюидных включений в кварце рудных тел участков Штокового рудного поля

Table 5. Results of the microthermometry studies of fluid inclusions in the Shtokovoye ore field quartz

\begin{tabular}{|c|c|c|c|c|c|c|c|c|c|}
\hline $\begin{array}{c}\text { Видимая } \\
\text { фаза }\end{array}$ & КH & $\begin{array}{l}\text { Тгом., } \\
{ }^{\circ} \mathrm{C}\end{array}$ & $\begin{array}{l}\text { Тэвт., } \\
{ }^{\circ} \mathrm{C}\end{array}$ & $\begin{array}{c}\text { Тпл. льда, } \\
{ }^{\circ} \mathrm{C}\end{array}$ & $\begin{array}{c}\text { Тпл. } \mathrm{CO}_{2} \text {, } \\
{ }^{\circ} \mathrm{C}\end{array}$ & $\begin{array}{c}\text { Тгом. } \mathrm{CO}_{2}, \\
{ }^{\circ} \mathrm{C}\end{array}$ & $\begin{array}{c}\text { Тпл. гг, } \\
{ }^{\circ} \mathrm{C}\end{array}$ & $\begin{array}{l}\text { C мас.\%- } \\
\text { экв. } \mathrm{NaCl}\end{array}$ & $\begin{array}{l}\mathrm{dCO}_{2}, \\
\Gamma / \mathrm{CM}^{3}\end{array}$ \\
\hline \multicolumn{10}{|c|}{ Участок «Галлюцинация» } \\
\hline LC & 30 & $\underline{383}$ & - & - & $-58,1$ & 13 & - & - & 0.1 \\
\hline LC & $50 \ldots 80$ & $325 \ldots 331$ & - & - & $-57 \ldots-58.2$ & $16.8 \ldots 17.4$ & 9.5 & - & $\underline{0.2}$ \\
\hline $\mathrm{C}$ & 0 & 320 д & - & - & -59 & 12.7 & - & - & $\overline{0,1}$ \\
\hline LC & $50 \ldots 70$ & $290 \ldots 320$ & - & - & $-59 \ldots-58.3$ & $12.3 \ldots 13$ & 10.1 & - & 0.1 \\
\hline $\mathrm{LC}$ & $30 . .70$ & $243 \ldots 280$ & - & - & $-57.7 \ldots-56.7$ & $14 \ldots 20.3$ & $5.8 \ldots 9$ & - & 0.2 \\
\hline $\mathrm{L}$ & 50 & $330 \ldots 350$ & -21 & -6 & - & - & - & $\underline{9.2}$ & - \\
\hline $\mathrm{L}$ & $50 \ldots 60$ & $310 \ldots 315$ & - & -1.9 & - & - & - & 3.2 & - \\
\hline $\mathrm{L}$ & $50 \ldots 70$ & 280 & -28 & $-1 \ldots-0.7$ & - & - & - & 1.2 & - \\
\hline $\mathrm{L}$ & $50 \ldots 80$ & $240 \ldots 258$ & -25 & $-3.7 \ldots-0.8$ & - & - & - & $1.3 \ldots 6$ & - \\
\hline LC & $70 \ldots 80$ & 227 & - & - & -58.2 & 11.9 & - & - & 0.1 \\
\hline $\mathrm{L}$ & $70 \ldots 80$ & $219 \ldots 220$ & -21 & -6 & - & - & - & 9.2 & - \\
\hline $\mathrm{L}$ & $70 \ldots 90$ & 200 & - & -0.7 & - & - & - & 1.2 & - \\
\hline $\mathrm{L}$ & 80 & $158 \ldots 160$ & -25 & $-2.7 \ldots-2.4$ & - & - & - & $4 \ldots 4.5$ & - \\
\hline LC & 70 & 152 & - & - & -58.1 & 13 & - & - & 0.1 \\
\hline \multicolumn{10}{|c|}{ Участок «Штоковый» } \\
\hline $\mathrm{LC}$ & 70,0 & $336 \ldots .412$ & - & - & -56.4 & 21.6 & - & - & 0.2 \\
\hline LC & $20 \ldots 30$ & 330 & - & - & $-57.9 \ldots-57$ & 8.1 & - & - & 0.1 \\
\hline LC & $50 \ldots 70$ & $260 \ldots 328$ & - & - & $-59.1 \ldots-56.1$ & $11 \ldots 25.7$ & - & - & $0.1 \ldots 0.2$ \\
\hline $\mathrm{L}$ & $70 \ldots 90$ & $250 \ldots 318$ & -22 & $-6.6 \ldots-2$ & - & - & - & $3.4 \ldots 10$ & - \\
\hline $\mathrm{L}$ & 80.0 & $247 \ldots 250$ & -27 & $-0.8 \ldots-0.5$ & - & - & - & $1.4 \ldots 0.9$ & - \\
\hline $\mathrm{L}$ & $70 \ldots 90$ & $131 \ldots 240$ & $-22 \ldots-20$ & $-4.3 \ldots-0.8$ & - & - & - & $6.6 \ldots 1.4$ & - \\
\hline $\mathrm{C}$ & 0.0 & 200 Д & - & - & $-56.7 \ldots-56.4$ & 24 & - & - & 0.1 \\
\hline
\end{tabular}

Примечание. Каждая строчка характеризует группу включений (не менее 3) с близкими РТХ-параметрами; Д декрипитация; «-» - соответствующий фазовый переход отсутствует или не ясно выражен; КН - коэффициент наполнения флюидного включения (см. методику); цифры в таблице, выделенные полужирным шрифтом: подчеркнутые - максимальные значения, не подчеркнутые - минимальные.

температур не наблюдается (рис. 8), что, согласно (Wilkinson, 2001), свидетельствует о том, что рудообразующая система эволюционировала по сценарию охлаждения, т. е. без проникновения в нее внешних, разбавляющих рудообразующий флюид растворов и без процесса «вскипания» флюида. Таким образом, можно допустить, что руды Штокового рудного поля формировались в закрытой системе (Прокофьев, 2000).

\section{ВЫВОДЫ}

Минерализация Штокового рудного поля по своей геологической позиции, включая состав и возраст ассоциирующих гранитоидов, вещественному составу руд и условиям их образования соответствует «глубинной» группе золоторедкометалльной формации (Vikent'eva et al., 2010) Северо-Востока Азии (см. табл. 6). Это объекты, сформированные на глубине 6-8 км при давлении 1.5-2 кбар (Кряжев, 2017) умеренноконцентрированными (6-10 $\mathrm{NaCl}$ экв. \%) растворами. К ним относятся рудопроявления Бутарное (Волков и др., 2013), Басугуньинское (Альшев- ский, 2009), Дубач (Vikent'eva et al., 2018), Надежда (Глухов и др., 2016).

Спецификой Штокового рудного поля являются: 1) наличие арсенопирита с высоким соотношением S/As и значительной разницей в содержании мышьяка в разных его генерациях (I - 29-33 ат.\%, II - 31-35 ат.\%); 2) развитие акантита, блеклых руд, сульфосолей серебра, а также низкопробного самородного золота (425-474\%o); 3) близкий геохимический спектр руд участков «Штоковый» (Au-As-Sb-Bi-Ag-Co-W-Mo-Pb-Sn) и «Галлюцинация» (As-Au-Sb-Ag-Bi-Co-W-Pb-Mo-Zn-Sn); золото-серебряное отношение 0.1 .

Определено, что рудообразование происходило в три этапа: 1 - метасоматический; 2 гидротермально-метасоматический, состоящий из трех стадий (кварц-гидрослюдисто-сульфидной, кварц-сульфидной, золото-серебряной с халцедоновидным кварцем); 3 - гипергенный.

Выявлено, что руды были сформированы высоко-, среднетемпературным (от $412^{\circ} \mathrm{C}$ ), средне-, низкоконцентрированным (10-0.9 мас.\% экв. $\mathrm{NaCl}$, , углекислотно-водно-солевым (хлоридным) гидротермальным флюидом. 

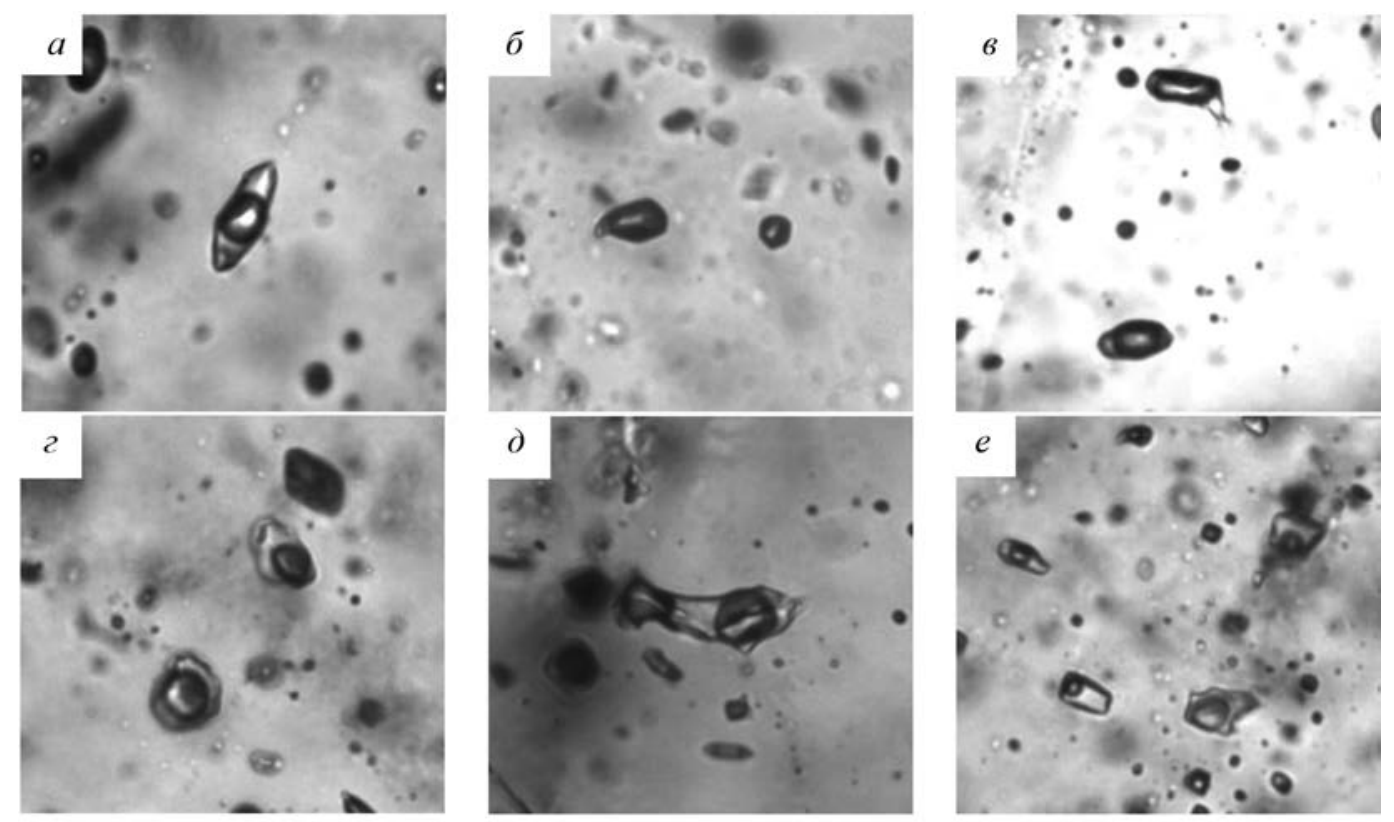

$20 \mu \mathrm{m}$

Puc. 5. Типы флюидных включений в кварце рудных тел Штокового рудного поля: $a$ - газово-жидкое (L-Tип); $\sigma$ - газово-жидкие, углекислотно-водные (LC-тип); в - газовые, углекислотные (C-тип); г-e - совместное расположение ФВ L-типа и LC-типа

Fig. 5. Types of fluid inclusions in the Shtockovoye ore field quartz: $a$ - gas-liquid (L-type); $\sigma-$ gas-liquid, $\mathrm{CO}_{2}-$ $\mathrm{H}_{2} \mathrm{O}$ (LC-type); 6 -gaseous, carbon-dioxide (C-type); $-e-$ mutual arrangement of L- and LC-type inclusions

Таблица 6. Результаты КР-спектрометрии газовых составляющих ФВ в кварце рудных тел Штокового рудного поля

Table 6. Raman spectrometry results for gas components of the fluid inclusions in quartz from the Shtokovoye ore bodies

\begin{tabular}{|c|c|c|c|c|c|c|c|}
\hline № образца & Компонент & $\Delta$ & $\mathrm{dCO}_{2}, \Gamma / \mathrm{cm}^{3}$ & S пика, у. е. & $\sigma$ & $\zeta$ & $\begin{array}{c}\text { Мольная доля компонента, } \\
\% \\
\end{array}$ \\
\hline & ${ }^{12} \mathrm{CO}_{2}(\mathrm{~s})$ & \multirow{2}{*}{102.9} & \multirow{2}{*}{0.2} & 3411.7 & 1.0 & 0.5 & \multirow{2}{*}{97.3} \\
\hline & ${ }^{12} \mathrm{CO}_{2}$ (vs) & & & 5391.7 & 1.5 & 0.5 & \\
\hline & $\mathrm{H}_{2} \mathrm{~S}$ & & & 0.0 & 6.4 & 1.0 & 0.0 \\
\hline & $\mathrm{CH}_{4}$ & & & 1897.7 & 7.5 & 1.0 & 1.8 \\
\hline & $\mathrm{N}_{2}$ & & & 127.3 & 1.0 & 1.0 & 0.9 \\
\hline \multirow{5}{*}{$245 x^{2}$} & ${ }^{12} \mathrm{CO}_{2}(\mathrm{~s})$ & \multirow{2}{*}{102.9} & \multirow{2}{*}{0.2} & 762.3 & 1.0 & 0.5 & \multirow{2}{*}{95.1} \\
\hline & ${ }^{12} \mathrm{CO}_{2}$ (vs) & & & 1134.8 & 1.5 & 0.5 & \\
\hline & $\mathrm{H}_{2} \mathrm{~S}$ & & & 0.0 & 6.4 & 1.0 & 0.0 \\
\hline & $\mathrm{CH}_{4}$ & & & 943.6 & 7.5 & 1.0 & 3.9 \\
\hline & $\mathrm{N}_{2}$ & & & 30.4 & 1.0 & 1.0 & 1.0 \\
\hline \multirow{3}{*}{$-\sqrt{2}=0$} & ${ }^{12} \mathrm{CO}_{2}(\mathrm{~s})$ & \multirow{2}{*}{102.9} & \multirow{2}{*}{0.2} & 6101.3 & 1.0 & 0.5 & \multirow{2}{*}{68.6} \\
\hline & ${ }^{12} \mathrm{CO}_{2}$ (vs) & & & 10509.6 & 1.5 & 0.5 & \\
\hline & $\mathrm{HS}^{-}$ & & & 188.9 & 6.4 & 1.0 & 0.1 \\
\hline \multirow{7}{*}{ 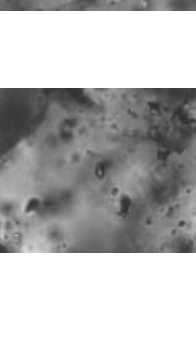 } & $\mathrm{CH}_{4}$ & & & 42554.2 & 7.5 & 1.0 & 14.9 \\
\hline & $\mathrm{N}_{2}$ & & & 6288.5 & 1.0 & 1.0 & 16.5 \\
\hline & ${ }^{12} \mathrm{CO}_{2}(\mathrm{~s})$ & \multirow{2}{*}{103.5} & \multirow{2}{*}{0.4} & 3834.0 & 1.0 & 0.5 & \multirow{2}{*}{93.5} \\
\hline & ${ }^{12} \mathrm{CO}_{2}$ (vs) & & & 6524.6 & 1.5 & 0.5 & \\
\hline & $\mathrm{H}_{2} \mathrm{~S}$ & & & 0.0 & 6.4 & 1.0 & 0.0 \\
\hline & $\mathrm{CH}_{4}$ & & & 8620.6 & 7.5 & 1.0 & 6.6 \\
\hline & $\mathrm{N}_{2}$ & & & 0.0 & 1.0 & 1.0 & 0.0 \\
\hline
\end{tabular}


Окончание табл. 6

\begin{tabular}{|c|c|c|c|c|c|c|c|}
\hline № образца & Компонент & $\Delta$ & $\mathrm{dCO}_{2}, \Gamma / \mathrm{cm}^{3}$ & S пика, у. е. & $\sigma$ & $\zeta$ & $\begin{array}{c}\text { Мольная доля компонента, } \\
\%\end{array}$ \\
\hline Ш-208 & ${ }^{12} \mathrm{CO}_{2}(\mathrm{~s})$ & \multirow{2}{*}{102.9} & \multirow{2}{*}{0.2} & 14635.2 & 1.0 & 0.5 & \multirow{2}{*}{68.7} \\
\hline \multirow{5}{*}{ 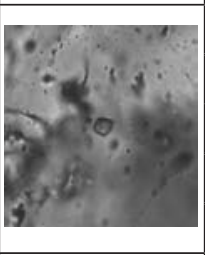 } & ${ }^{12} \mathrm{CO}_{2}$ (vs) & & & 25954.8 & 1.5 & 0.5 & \\
\hline & $\mathrm{HS}^{-}$ & & & 141.5 & 6.4 & 1.0 & 0.0 \\
\hline & $\mathrm{H}_{2} \mathrm{~S}$ & & & 101.2 & 7.5 & 1.0 & 0.0 \\
\hline & $\mathrm{CH}_{4}$ & & & 26233.0 & 1.0 & 1.0 & 28.2 \\
\hline & $\mathrm{N}_{2}$ & & & 2912.9 & 1.0 & 1.0 & 3.1 \\
\hline Ш-209 & ${ }^{12} \mathrm{CO}_{2}(\mathrm{~s})$ & \multirow{2}{*}{102.9} & \multirow{2}{*}{0.2} & 5819.4 & 1.0 & 0.5 & \multirow{2}{*}{96.8} \\
\hline \multirow{4}{*}{$0^{\circ} 0^{\circ}$} & ${ }^{12} \mathrm{CO}_{2}$ (vs) & & & 13160.5 & 1.5 & 0.5 & \\
\hline & $\mathrm{H}_{2} \mathrm{~S}$ & & & 41.7 & 6.4 & 1.0 & 0.0 \\
\hline & $\mathrm{CH}_{4}$ & & & 5752.1 & 7.5 & 1.0 & 2.5 \\
\hline & $\mathrm{N}_{2}$ & & & 199.1 & 1.0 & 1.0 & 0.7 \\
\hline Ш-209 & ${ }^{12} \mathrm{CO}_{2}(\mathrm{~s})$ & \multirow{2}{*}{104.8} & \multirow{2}{*}{1.0} & 19275.1 & 1.0 & 0.5 & \multirow{2}{*}{95.6} \\
\hline \multirow{4}{*}{ 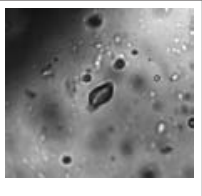 } & ${ }^{12} \mathrm{CO}_{2}$ (vs) & & & 32946.7 & 1.5 & 0.5 & \\
\hline & $\mathrm{H}_{2} \mathrm{~S}$ & & & 115.4 & 6.4 & 1.0 & 0.0 \\
\hline & $\mathrm{CH}_{4}$ & & & 18603.6 & 7.5 & 1.0 & 2.9 \\
\hline & $\mathrm{N}_{2}$ & & & 1264.9 & 1.0 & 1.0 & 1.5 \\
\hline E-012 & ${ }^{12} \mathrm{CO}_{2}(\mathrm{~s})$ & \multirow{2}{*}{104.8} & \multirow{2}{*}{1.0} & 190349.2 & 1.0 & 0.5 & \multirow{2}{*}{99.8} \\
\hline \multirow{4}{*}{$\therefore: 00$} & ${ }^{12} \mathrm{CO}_{2}$ (vs) & & & 24907.5 & 1.5 & 0.5 & \\
\hline & $\mathrm{H}_{2} \mathrm{~S}$ & & & 140.9 & 6.4 & 1.0 & 0.0 \\
\hline & $\mathrm{CH}_{4}$ & & & 2852.3 & 7.5 & 1.0 & 0.1 \\
\hline & $\mathrm{N}_{2}$ & & & 393.6 & 1.0 & 1.0 & 0.1 \\
\hline
\end{tabular}

Примечание. $\sigma$ - комбинационное рассеивание $(514.5 \mathrm{~nm}$ ) и $\zeta$ - инструментальный эффект (по Frezzotti et al., 2012); dCO рассчитано (по Wang, 2011); S пика и мольная доля компонентов рассчитаны по методике, приведенной в работе (Frezzotti et al., 2012).
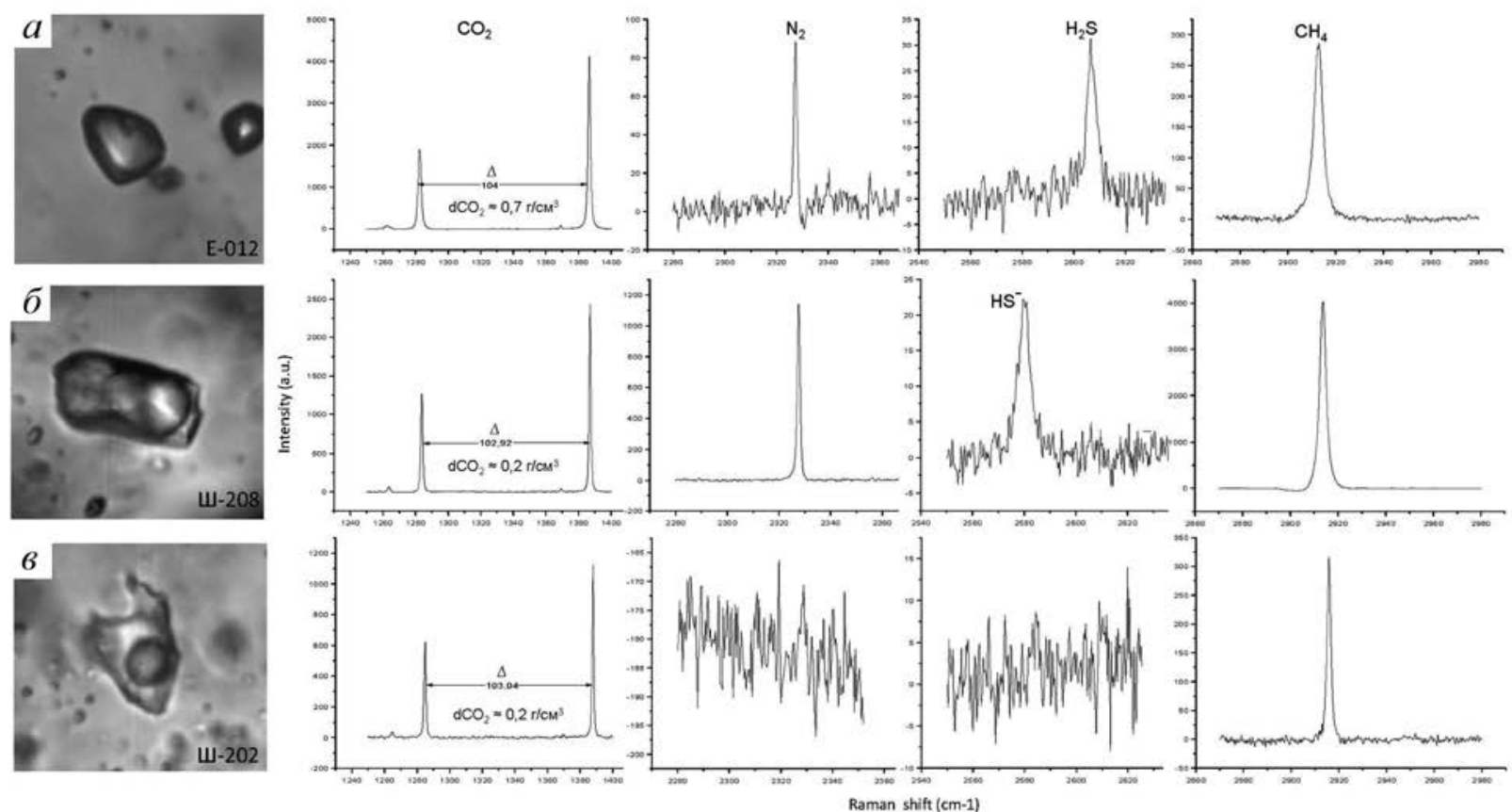

Puc. 6. КР-спектры типичных флюидных включений в кварце рудных тел Штокового рудного поля: $a$ - газового; $\sigma$ - газово-жидкого (углекислотного); в - газово-жидкого

Fig. 6. Raman spectra of typical fluid inclusions in the Shtokovoye ore field quartz: $a-$ gas; $\sigma-$ gas-liquid $\left(\mathrm{CO}_{2}\right)$; в- gas-liquid 
Их образование проходило в закрытой системе, по сценарию остывания. Изучение ФВ выявило два периода, в которые более интенсивно шла кристаллизация кварца: 1) $340-300^{\circ} \mathrm{C}$ (общий для обоих участков) в присутствии преимущественно углекислотного флюида; 2) 260 $240^{\circ} \mathrm{C}$ («Галлюцинация») и $240-220^{\circ}$ («Штоковый») в окружении водносолевого углекислотного флюида. КР-спектрометрией в газовых фазах ФВ установлено значительное количество $\mathrm{CO}_{2}, \mathrm{CH}_{4}, \mathrm{HS}^{-}$и $\mathrm{H}_{2} \mathrm{~S}, \mathrm{~N}_{2}$, при этом $\mathrm{CO}_{2}$ высокой плотности идентифицирована во ФВ кварца участка «Галлюцинация».

Выявленные различия РТХпараметров для участков предположительно обусловлены различиями вмещающей среды (граниты, алев-

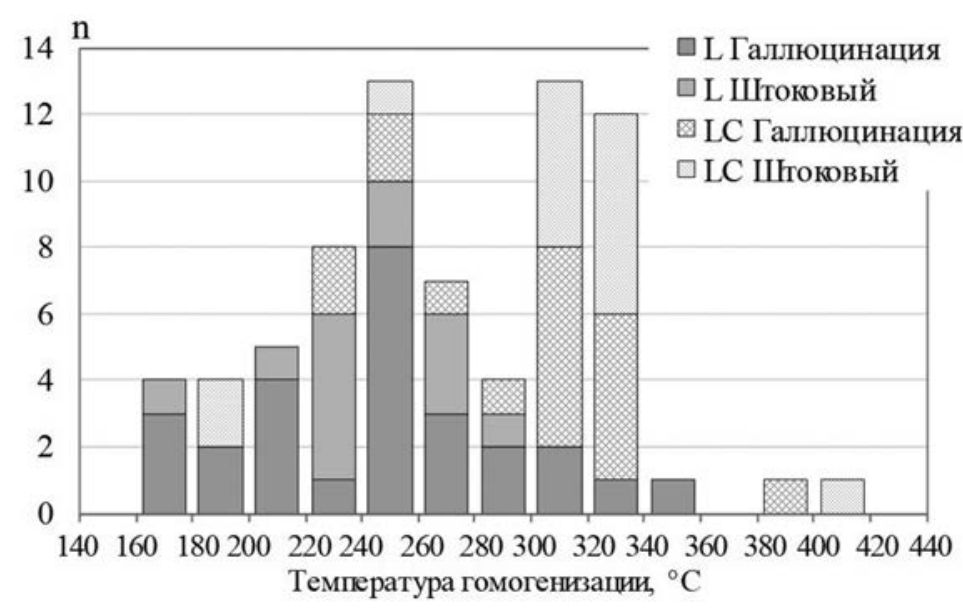

Puc. 7. Распределение температур гомогенизации ФВ разных типов в кварце рудных тел Штокового рудного поля

Fig. 7. Distribution of homogenization temperatures of differenttype fluid inclusions in the Shtokovoye ore field quartz ролиты и песчаники). Источником низкокипящих газов могли быть богатые органическим веществом осадочные породы, которые подверглись контактовому метаморфизму при внедрении штока гранитоидов (Naden, Shepherd, 1989; Гибшер и др., 2011).

В установленном температурном диапазоне от 412 до $200^{\circ} \mathrm{C}$, согласно фазовым диаграммам для систем $\mathrm{Fe}-\mathrm{As}-\mathrm{S}$ (Kretschmar, Scott, 1976), арсенопирит с содержанием As 30 ат.\% может кристаллизоваться при вариации $\log \mathrm{fS}_{2}$ от -6.5 до -10.3; в этих условиях он сосуществует с пиритом. Арсенопирит I c As 29-33 ат. \% может образоваться в интервале от $420^{\circ} \mathrm{C}$ и $\log \mathrm{fS}_{2}-10.5$

до $330^{\circ} \mathrm{C}$ и $\log \mathrm{fS}_{2}-13$ по линии сосуществования арсенопирит - пирротин. Переход от первой генерации ко второй (As 31-35 ат. \%), при условии, что это не связано с процессами, несущими новый прогрев системы выше $400^{\circ} \mathrm{C}$, а это опровергается отношением S/As и данными ТБГ, возможен, если при температуре $350^{\circ} \mathrm{C}$ резко снизилась активность серы от $\log \mathrm{fS}_{2}-8$ до -12.5 .

Специфической особенностью руд Штокового рудного поля является наличие золотосеребряной минерализации. О ее эпитермальном характере свидетельствует (по Г. Н. Гамянину, 2001) ассоциация с жилами халценодовидного
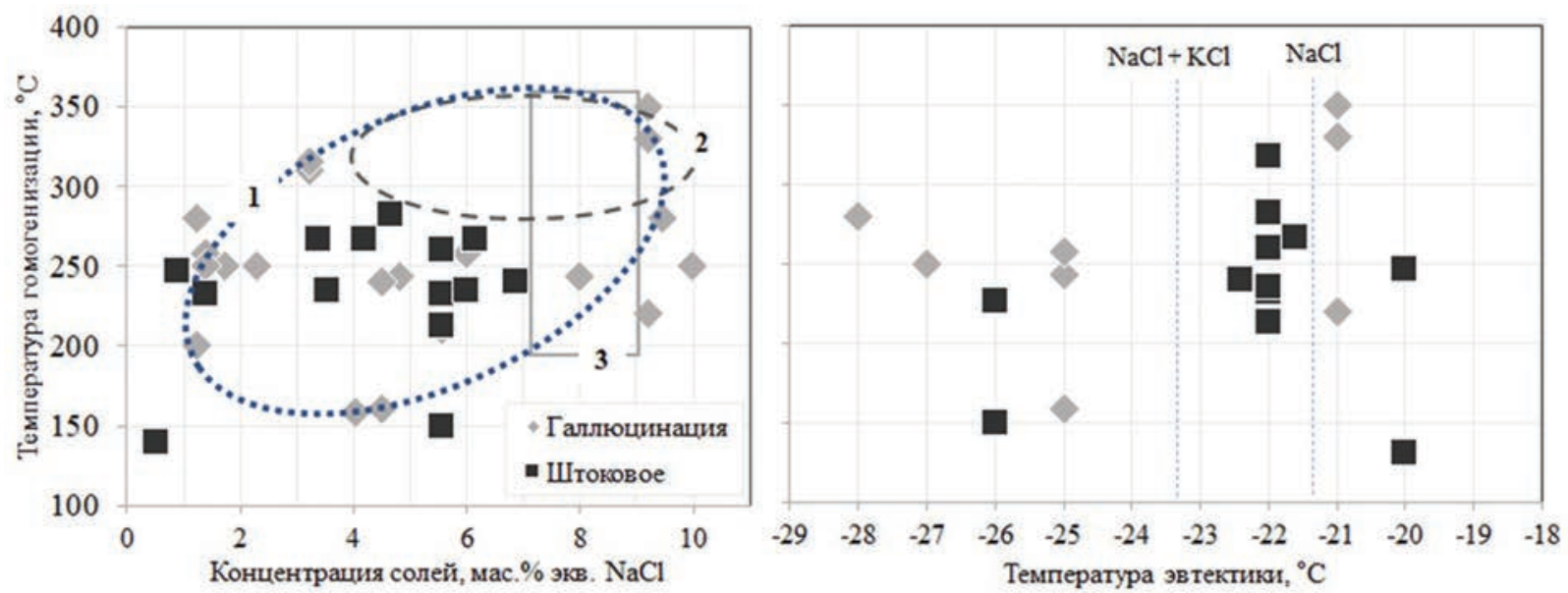

Puc. 8. Диаграммы соотношений температура гомогенизации - концентрация (соленость) - температура эвтектики по данным изучения индивидуальных ФВ в кварце рудных тел Штокового рудного поля. Цифрами обозначены области локализации параметров ФВ в кварце: 1 - месторождения Школьное (Волков и др., 2011); 2 - Родионовское; 3 - Игуменовское (Волков и др., 2017)

Fig 8. Ratio diagrams for homogenization temperatures - concentration (salinity) - eutectic temperature according to the data from studying individual fluid inclusions in the Shtokovoye ore field quartz. Numbers indicate localizations of FI parameters in quartz: 1 - Shkol'noye (Volkov et al., 2011); 2 - Rodionovskoye; 3 - Igumenovskoye (Volkov et al., 2017) 
кварца, высокие ( > 30\%) содержания серебра и преобладание железа над цинком в химическом составе блеклых руд, а также отношение S/As 0.9-1.23 в арсенопирите и отсутствие ТБГ признаков прогрева рудной системы выше $412^{\circ} \mathrm{C}$.

Формирование поздней золото-серебряной минерализации Штокового рудного поля и Хурчан-Оротуканской зоны ТМА в целом мы, как и другие исследователи (Горячев, 1998; Кузнецов и др., 2011), связываем с процессами формирования Охотско-Чукотского вулканогенного пояса. В этом отношении наиболее близким аналогом рассматриваемой минерализации является месторождение Школьное (Волков и др., 2011). Следует отметить также принципиальное отличие данной группы объектов от другой, которую представляют рудопроявления Улахан (Савва, 2018) и Глухаринское (Глухов и др., 2018). Для нее характерен более ранний возраст эпитермального Au-Ag оруденения, которое связано с более ранними, нежели ОЧВП, доаккреционными магматическими дугами: Удско-Мургальским (Улахан) и Уяндино-Ясачненским (Глухаринское) вулканогенными поясами.

\section{БЛАГОДАРНОСТИ}

Авторы благодарят заместителя директора Магаданского филиала АО «Полиметалл УК» С. Ф. Петрова за предоставленную каменную коллекцию; заместителя директора по научной работе С. З. Смирнова и заведующего лабораторией термобарогеохимии А. А. Томиленко за предоставленную возможность выполнить исследования на дисперсионном Раман-микроскопе Lab Ram HR (Институт геологии и минералогии CO PAН, г. Новосибирск).

\section{ЛИТЕРАТУРА}

Альшевский А. В. Геология, особенности вещественного состава, генезис и перспективы золотого оруденения в Утинском узле : автореф. дис. ... канд. геол.-минер. наук. Владивосток, 2009. 60 с.

Борисенко А. С. Изучение солевого состава газовожидких включений в минералах методом криометрии // Геология и геофизика. 1977. № 8. С. 16-27.

Волков А. В., Прокофьев В. Ю., Тюкова Е. Э., Сидоров В. А., Мурашов К. Ю., Сидорова Н. В., Земскова $M$. A. Новые данные по геологии и геохимии золотокварцевого месторождения Родионовское (СевероВосток России) // Геология рудных месторождений. 2017. T. 59, № 2. С. 99-112.

Волков А. В., Савва Н. Е., Сидоров А. А., Прокофьев В. Ю., Горячев Н. А., Вознесенский С. Д., Альшевский А. В., Чернова А. Д. Золоторудное месторождение Школьное // Там же. 2011. Т. 53, № 1. С. 3-31.

Волков А. В., Черепанова Н. В., Прокофьев В. Ю., Савва Н. Е., Смильгин С. В., Трубкин Н. В., Алексеев $B$. Ю. Месторождение золота в гранитоидном штоке
Бутарный (Северо-Восток России) // Там. же. 2013. Т. 55, № 3. С. 214-237.

Гамянин Г. Н. Минералого-генетические аспекты золотого оруденения Верхояно-Колымских мезозоид. Москва : Геос, 2001. 222 с.

Гамянин Г. Н., Горячев Н. А., Бахарев А. Г., Колесниченко П. П., Зайцев А. И., Диман Е. Н., Бердников H. B. Условия зарождения и эволюции золоторудно-магматических систем в мезозоидах Северо-Востока Азии. Магадан : СВКНИИ ДВО PAH, 2003. $196 \mathrm{c}$.

Геодинамика, магматизм и металлогения Востока России / ред. А. И. Ханчук : в 2-х кн. Владивосток : Дальнаука, 2006. Кн. 1. 572 с.

Гибшер Н. А., Томиленко А. А., Сазонов А. М., Рябуха М. А., Тимкина А. Л. Золоторудное месторождение Герфед: характеристика флюидов и РТ-условия образования кварцевых жил (Енисейский кряж, Россия) // Геология и геофизика. 2011. Т. 52, № 11. C. 1851-1867.

Глухов А. Н., Савва Н. Е., Буляков Г. Х., Фомина M. И., Бирюков A. А. Самородное золото в рудах и россыпях Глухаринского узла, Магаданская область // Руды и металлы. 2018. № 2. С. 55-64.

Глухов А. Н., Савва Н. Е., Колова Е. Е. Вещественный состав и генезис золотых руд месторождения Надежда, Магаданская область // Там же. 2016. № 4. C. 60-71.

Горячев H. A. Геология мезозойских золотокварцевых жильных поясов Северо-Востока Азии. Магадан : СВКНИИ ДВО РАН, 1998. 210 с.

Горячев Н. А. Происхождение золото-кварцевых жильных поясов Северной Пацифики. Магадан : СВКНИИ ДВО РАН, 2003. 143 с.

Ермаков Н. П., Долгов Ю. А. Термобарогеохимия. Москва : Недра, 1979. 271 с.

Калюжный B. А. Основы учения о минералообразующих флюидах. Киев : Наукова думка, 1982. 240 с.

Кряжев С. Г. Генетические модели и критерии прогноза золоторудных месторождений в углеродистотерригенных комплексах : автореф. ... д. г.-м. н. Москва, 2017. 122 с.

Кузнецов B. M. Разнопорядковые структуры тектоно-магматической активизации в ВерхояноЧукотской складчатой области // Вестник СевероВосточного научного центра ДВО РАН. 2006. № 2. C. 2-12.

Кузнеияов В. М., Горячев Н. А., Жигалов С. В., Савва H. E. Структура и рудоносность МякитХурчанского рудно-россыпного узла // Там же. 2011. № 4. C. 37-51.

Литвиненко И. С. О формационной принадлежности золотого оруденения Верхне-Мякитского руднороссыпного узла (Северо-Восток России) / Форум «Наука Северо-Востока России: фундаментальные и прикладные исследования в Северной Пацифике и Арктике». Магадан, 5-6 марта 2020 г. Магадан : СВКНИИ ДВО РАН, 2020. С. 104-108.

Мельников Ф. П., Прокофьев В. Ю., Шатагин H. Н. Термобарогеохимия. Москва : Акад. Проект, 2008. 222 c. 
Прокофьев В. Ю. Геохимические особенности рудообразующих флюидов гидротермальных месторождений золота различных генетических типов (по данным исследования флюидных включений). Новосибирск : Наука; Сиб. издат. фирма РАН, 2000. 192 c.

Рёддер Э. Флюидные включения в минералах. Москва : Мир, 1987. Т. 1.560 с.

Савва Н. Е. Минералогия серебра Северо-Востока России. Москва : Триумф, 2018. 518 с.

Тюкова Е. Э., Ворошин С. В. Состав и парагенезисы арсенопирита в месторождениях и вмещающих породах Верхне-Колымского региона. Магадан : СВНЦ ДВО РАН, 2007. 107 c.

Шило Н. А., Гончаров В. И., Альшевский А. В., Ворцеепнев $B$. $B$. Условия формирования золотого оруденения в структурах Северо-Востока СССР. Москва : Наука, 1988. 181 c.

Bodnar R. J., Vityk M. O. Interpretation of microthermometric data for $\mathrm{H}_{2} \mathrm{O}-\mathrm{NaCl}$ fluid inclusions // Fluid inclusions in minerals: methods and application / Ed. by Benedetto De Vivo, Maria Luce Frezzotti. PontignanoSiena, 1994. P. 117-130.

Brown P. E., Lamb W. M. P-V-T properties of fluids in the system $\mathrm{H}_{2} \mathrm{O} \pm \mathrm{CO}_{2} \pm \mathrm{NaCl}$ : New graphical presentations and implications for fluid inclusion studies // Geochimica et Cosmochimica Acta. 1989. Vol. 53, No. 6. P. 1209-1221.

Frezzotti M. L., Tecce F., Casagli A. Raman spectroscopy for fluid inclusion analysis // Journal of Geochemical Exploration. 2012. Vol. 112, No. 112. P. 1-20.
Hart C. J .R. Reduced Intrusion-Related Gold Systems // Mineral deposits of Canada: A Synthesis of Major Deposit Types, District Metallogeny, the Evolution of Geological Provinces, and Exploration Methods: Geological Association of Canada, Mineral Deposits Division, Special Publication. 2007. No. 5. P. 95-112.

Kretschmar U., Scott $S$. D. Phase relations involving arsenopyrite in the system $\mathrm{Fe}-\mathrm{As}-\mathrm{S}$ and their application // Canadian Mineralogist. 1976. Vol. 14, No. 3. P. 364-386.

Mair J. L., Farmer G. L., Groves D. I., Hart C. J. R., Goldfarb R. J. Petrogenesis of Postcollisional Magmatism at Scheelite Dome, Yukon, Canada: Evidence for a Litospheric Mantle Source for Magmas Associated with Intrusion-Related Gold Systems // Economic Geology. 2011. Vol. 106. P. 451-480.

Naden J., Shepherd Th. Role of methane and carbon dioxide in gold deposition // Nature. 1989. Vol. 342, No. 6521. P. 793-795.

Vikent'eva O. V., Prokofiev V. Yu., Gamyanin G. N., Goryachev N. A., Bortnikov N. S. Intrusion-related goldbismuth deposits of North-East Russia: PTX parameters and sources of hydrothermal fluids // Ore Geology Reviews. 2018. Vol. 102. P. 240-259.

Wang $X$. Raman spectroscopic measurements of $\mathrm{CO}_{2}$ density: Experimental calibration with high-pressure optical cell (HPOC) and fused silica capillary capsule (FSCC) with application to fluid inclusion observations // Geochimica et Cosmochimica Acta. 2011. Vol. 75, No. 14. P. 4080-4093.

Wilkinson J. J. Fluid inclusions in hydrothermal ore deposits // Lithos. 2001. Vol. 55, No. 1-4. P. 229-272.

Поступила в редакичию 03.06.2020 2.

Поступила после доработки 21.12.2020 2.

\title{
GOLD MINERALIZATION OF THE SHTOKOVOYE ORE FIELD (Magadan Oblast)
}

\author{
A. N. Glukhov, M. I. Fomina, E. E. Kolova
}

\section{North-East Interdisciplinary Sciences Research Institute n. a. Shilo, FEB RAS, Magadan}

The authors briefly characterize the geology and structure of the Shtokovoye ore field attached to the area where the Khurchan-Orotukan zone of tectonic-magmatic activation overlays the structures of the Yana-Kolyma ore-bearing belt. Studied are mineral associations and physicochemical conditions of gold ore bodies, located both in granites and in hornfelsed sedimentary masses. By the main features of its geological structure, ore composition, and physicochemical formation conditions, the Shtokovoye ore field mineralization corresponds to the "depth" group of the gold-rare-metal formation, analogous to the Butarnoye, Basugunyinskiye, Dubach, and Nadezhda occurrences. Its ores are peculiar in the late epithermal mineralization, which is associated with the Okhotsk-Chukotka volcanic belt and overlays the sinaccretional gold-rare-metal mineralization.

Keywords: granitoid-related, gold, granite, gold-silver, mineralogy, thermobarogeochemistry, Knurchan-Orotukan zone. 


\section{REFERENCES}

Al'shevsky, A. V., 2009. Geology, Essential Composition Features, Genesis, and Perspectives of Gold Mineralization in the Utinsky Knot. Vladivostok [In Russian].

Bodnar, R. J., Vityk, M. O., 1994. Interpretation of Microtherrmometric Data for $\mathrm{H}_{2} \mathrm{O}-\mathrm{NaCl}$ Fluid Inclusions, Fluid Inclusions in Minerals: Methods and Application. 117-130.

Borisenko, A. S., 1977. Study of Salt Composition of Fluid Inclusions in Minerals by Cryometry, Russian Geology and Geophisics. 8, 16-27 [In Russian].

Brown, P. E., Lamb, W. M., 1989. P-V-T Properties of Fluids in the System $\mathrm{H}_{2} \mathrm{O} \pm \mathrm{CO}_{2} \pm \mathrm{NaCl}$ : New Graphical Presentations and Implications for Fluid Inclusion Studies, Geochimica et Cosmochimica Acta. 53 (6), 12091221.

Frezzotti, M. L., Tecce, F., Casagli, A., 2012. Raman Spectroscopy for Fluid Inclusion Analysis, Journal of Geochemical Exploration. 112, 112, 1-20.

Gamyanin, G. N., 2001. Mineralogical-Genetic Aspects of Gold Mineralization of the Verkhoyansk-Kolyma Mezozoides. Moscow, GEOS [In Russian].

Gamyanin, G. N., Goryachev, N. A., Bakharev, A. G., Kolesnichenko, P. P., Zaitsev, A. I., Diman, E. N., Berdnikov, N. V., 2003. Conditions of Origin and Evolution of Granitoid Gold-Ore-Magmatic Systems in Mesozoids in North-East Asia. Magadan, NEISRI FEB RAS [In Russian].

Geodynamics, Magmatism and Metallogeny of the Russian East: in 2 Books. Ed. by A. I. Khanchuk, 2006. Vladivostok, Dalnauka [In Russian].

Gibsher N. A., Tomilenko A. A., Ryabukha M. A., Timkina, A. L., Sazonov, A. M., 2011. The Gerfed Gold Deposit: Fluids and PT-conditions for Quartz Vein Formation (Yenisei Ridge, Russia), Russian Geology and Geophysics. 52 (11), 1461-1473.

Glukhov, A. N., Savva, N. E., Bulyakov, G. H., Fomina, M. I., Biryukov, A. A., 2018. Native Gold in the Lode and Placers of the Glukhariny Knot, Magadan Region, Rudy $i$ Metally. 2, 55-64 [In Russian].

Glukhov, A. N., Savva, N. E., Kolova, E. E., 2016. Ore Mineralogy and Genesis of the Nadezhda Gold Deposit, Ibid. (4), 60-71 [In Russian].

Goryachev, N. A., 1998. Geology of Mezozoic GoldQuartz Vein Belts in the North-East of Asia. Magadan, NEISRI FEB RAS [In Russian].

Goryachev, N. A., 2003. Origin of Gold-Quartz Vein Belts of the North Pacific. Magadan, NEISRI FEB RAS [In Russian].

Hart, C. J.R., 2007. Reduced Intrusion-Related Gold Systems // Mineral Deposits of Canada: A Synthesis of Major Deposit Types, District Metallogeny, the Evolution of Geological Provinces, and Exploration Methods: Geological Association of Canada, Mineral Deposits Division, Special Publication. 5, 95-112.

Kalyuzhniy, V. A., 1982. The Basics of the Ore-Forming Fluid Theory. Kiev, Naukova Dumka [In Russian].

Kretschmar, U., Scott, S. D., 1976. Phase Relations Involving Arsenopyrite in the System $\mathrm{Fe}-\mathrm{As}-\mathrm{S}$ and Their Application, Canadian Mineralogist. 14, 3, 364-386.
Kryazhev, S. G., 2017. Genetic Models and Criteria of Assessing Gold Ore Deposits in Carboniferous-Terrigenous Complexes. Moscow [In Russian].

Kuznetsov, V. M., 2006. Different-Scale Structures of Tectonic and Magmatic Activation in the VerkhoyanskChukotka Fold Belt, Vestnik NECS FEB RAS. 2, 2-12 [In Russian].

Kuznetsov, V. M., Goryachev, N. A., Zhigalov, S. V., Savva, N. E., 2011. Structure and Ore Bearing of the Myakit-Khurchan Ore-Placer Knot, Ibid. 4, 37-51 [In Russian].

Litvinenko, I. S., 2020. Types of Gold Mineralization of the Myakit Ore Knot (Russia's North-East of the Russia), "Science in the Russian North-East: Fundamental and Applied Studies in the Northern Pacific and Arctic" Forum, Magadan, March 5-6, 2020. Magadan, NEISRI FEB RAS. 104-108 [In Russian].

Mair, J. L., Farmer, G. L., Groves, D. I., Hart, C. J. R., Goldfarb, R. J., 2011. Petrogenesis of Postcollisional Magmatism at Scheelite Dome, Yukon, Canada: Evidence for a Litospheric Mantle Source for Magmas Associated with Intrusion-Related Gold Systems, Economic Geology. 106, 451-480.

Mel'nikov, F. P., Prokofiev, V. Yu., Shatagin, N. N., 2008. Thermobarogeochemistry. Moscow, Academichesky Proekt [In Russian].

Naden, J., Shepherd Th., 1989. Role of Methane and Carbon Dioxide in Gold Deposition, Nature. 342 (6521), 793-795.

Prokofiev, V. Yu., 2000. Geochemical Features of Different-Type Ore-Forming Fluids in Hydrothermal Gold Deposits (by Data on Fluid Inclusions). Novosibirsk, Nauka [In Russian].

Roedder, E., 1987. Fluid Inclusions in Minerals. Moscow, Mir. 1 [In Russian].

Savva, N. E., 2018. Mineralogy of Silver in Northeast Russia. Moscow, Triumph [In Russian].

Shilo, N. A., Goncharov, V. I., Al'shevsky, A. V., Vortsepnev, V. V., 1988. Gold Ore-Forming Conditions in Structures of the North-East the USSR]. Moscow, Nauka [In Russian].

Tyukova, Ye. E., Voroshin, S. V., 2007. Arsenopyrite Mineral Composition and Parageneses in Ore Deposits and Host Rocks in the Upper Kolyma Area. Magadan, NEISRI FEB RAS [In Russian].

Vikent'eva, O. V., Prokofiev, V. Yu., Gamyanin, G. N., Goryachev, N. A., Bortnikov, N. S., 2018. Intrusion-Related Gold-Bismuth Deposits of North-East Russia: PTX Parameters and Sources of Hydrothermal Fluids, Ore Geology Reviews. 102, 240-259.

Volkov, A. V., Prokofiev, V. Y., Trubkin, N. V., Alekseev, V. Y., Cherepanova N. V., Smilgin, S. V., Savva N. E., 2013. Gold Deposit in the Butarny Granitoid Stock, Russian Northeast, Geology of Ore Deposits. 55 (3), 185-206.

Volkov, A. V., Prokofiev, V. Y., Tyukova, E. E., Murashov, K. Y., Sidorova, N. V., Zemskova, M. A., Sidorov, V. A., 2017. New Data for Geology and Geochemistry of the Rodion Gold-Quartz Deposit, Northeastern Russia, Ibid. 59, 2, 112-130. 
Volkov, A. V., Sidorov, A. A., Prokof'ev, V. Y., Savva, N. E., Goryachev, N. A., Al'shevsky, A. V., Voznesensky, S. D., Chernova, A. D., 2011. Shkol'noe Gold Deposit, the Russian Northeast, Geology of Ore Deposits. 53 (1), 1-26.

Wang, X., 2011. Raman Spectroscopic Measurements of $\mathrm{CO}_{2}$ Density: Experimental Calibration with HighPressure Optical Cell (HPOC) and Fused Silica Capillary
Capsule (FSCC) with Application to Fluid Inclusion Observations, Geochimica et Cosmochimica Acta. 75 (14), 4080-4093.

Wilkinson, J. J., 2001. Fluid Inclusions in Hydrothermal Ore Deposits, Lithos. 55 (1-4), 229-272.

Yermakov, N. P., Dolgov, Yu. A., 1979. Thermobarogeochemistry. Moscow, Nedra [In Russian]. 